\title{
Can the Trade-off Theory Explain Debt Structure?
}

\author{
Dirk Hackbarth \\ Washington University in St.Louis \\ Christopher A. Hennessy \\ University of California, Berkeley \\ Hayne E. Leland \\ University of California, Berkeley
}

\begin{abstract}
We examine the optimal mixture and priority structure of bank and market debt using a trade-off model in which banks have the unique ability to renegotiate outside formal bankruptcy. Flexible bank debt offers a superior trade-off between tax shields and bankruptcy costs. Ease of renegotiation limits bank debt capacity, however. Optimal debt structure hinges upon which party has bargaining power in private workouts. Weak firms have high bank debt capacity and utilize bank debt exclusively. Strong firms lever up to their (lower) bank debt capacity, augment with market debt, and place the bank senior. Therefore, the trade-off theory offers an explanation for: (i) why young/small firms use bank debt exclusively; (ii) why large/mature firms employ mixed debt financing; and (iii) why bank debt is senior. The trade-off theory also generates predictions consistent with international evidence. In countries in which the bankruptcy regime entails soft (tough) enforcement of contractual priority, bank debt capacity is low (high), implying greater (less) reliance on market debt. (JEL G13, G32, G33)
\end{abstract}

Existing trade-off models analyze the optimal amount of debt, but provide no guidance on debt structure, i.e. the mix of market versus nonmarket debt and specification of priority. The models are necessarily silent on these questions, since they assume that the firm issues a single class of debt. Most structural models approximate a firm with market debt, assuming that dispersion of creditors prevents renegotiation. A partial list of such models includes Brennan and Schwartz (1984), Kane et al. (1984), Fischer et al. (1989), Leland (1994), Goldstein et al. (2001), Titman and Tsyplakov (2003), and Strebulaev (2004). Conversely, the models of Anderson and Sundaresan (1996), Mella-Barral and Perraudin

\footnotetext{
We would like to thank seminar participants at the University of Wisconsin, University of Arizona, University of Houston, Humboldt University, Stanford University, the 2003 EFA Meetings, and the 2005 AFA Meetings. Special thanks to Paul Pfleiderer, Felix Meschke, and Ilya Strebulaev who served as discussants on this article. Address correspondence to Dirk Hackbarth, Finance Department, Olin School of Business, Washington University in St. Louis, One Brookings Drive, St. Louis, MO 63130, USA, or e-mail: hackbarth@wustl.edu.
} 
(1997), Mella-Barral (1999), Fan and Sundaresan (2000) and Hege and Mella-Barral (2000) assume that interest rate concessions can be obtained in costless bilateral renegotiations with a single creditor. These models approximate nonmarket debt, such as bank loans and private placements.

Existing trade-off models leave open three important questions. What is the optimal mix of nonmarket ("bank") and market debt? Does the choice between the two depend on firm characteristics? Finally, if it is indeed optimal to mix bank and market debt, what is the optimal contractual specification of priority? Our article answers these questions. This contributes to a growing literature on the testable implications of trade-off theory. Hennessy and Whited (2005), Leary and Roberts (2005), and Strebulaev (2004) analyze the implications of trade-off theory for leverage ratios, showing that the theory can be reconciled with existing empirical evidence. However, the fact that existing trade-off models fail to address debt structure leaves the theory open to criticism. For example, Hart and Moore (1995) argue that, "these approaches cannot explain the types of debt claims observed in practice."1

Reflecting this belief, corporate finance economists have turned to an ever-growing list of explanations such as market segmentation, scale economies in the flotation of market debt, certification by bank lenders, and monitoring incentives. We abstract from these rationales, employing a parsimonious pricing model featuring a tax shield-bankruptcy cost tradeoff. Ex ante, the firm has access to perfectly competitive capital markets, with all outside investors demanding the same expected after-tax riskadjusted rate of return. The only unique feature of the bank is its ability to renegotiate in a costless private workout. We follow Bulow and Shoven (1978) and Gertner and Scharfstein (1991) in assuming that payments to market lenders cannot be changed outside the formal bankruptcy process. Once the firm enters the bankruptcy process, the new owners can recapitalize optimally, although costs are incurred.

Most of our article is devoted to modeling a strong firm. The strong firm holds all bilateral bargaining power in the event of a private workout, in the sense that it can make take-it or leave-it debt service offers to the bank. This model approximates the environment facing large/mature corporations that are likely to be in a strong bargaining position ex post. ${ }^{2}$ Since the bank is able to grant (unilateral) interest rate concessions outside

\footnotetext{
1 They argue that trade-off theory predicts that firms will issue noncash-paying debt, such as PIK bonds, rather than cash-paying or "hard" debt. We note here that the 1989 Tax Act limited interest deductions for such claims in response to increased issuance of PIK bonds and other exotic debt instruments, which critics labeled “equity in drag." See Bulow et al. (1990).

${ }^{2}$ Bargaining power is readily endogenized. For example, large corporations are more likely to have inhouse counsel or bargaining expertise, which lowers marginal negotiation costs. In an alternating offer game, Rubinstein (1982) shows that the more efficient bargainer keeps more/all surplus. Under technical conditions, the right of first offer is irrelevant to the division of surplus. See Osborne and Rubinstein (1990), p 52.
} 
formal bankruptcy, bank debt entails lower bankruptcy costs. In fact, the Coase Theorem tells us that a firm relying exclusively on bank debt will always avoid costly bankruptcy, since the private workout process is efficient ex post.

Although bank debt is especially attractive, we show that the ability of the strong firm to issue bank debt is limited. Given that the strong firm can make take-it or leave-it offers, the value of bank debt cannot exceed the bank's reservation value - the value the bank would receive if it were to reject the firm's offer, opting to initiate formal bankruptcy. To maximize the firm's ability to raise this efficient form of debt capital, bank debt is placed senior. Consistent with this prediction, Carey (1995) finds that of the 18,000 loans made between 1986 and 1993 and recorded in the Dealscan database, over $99 \%$ of all bank loans contain a seniority clause. Mann (1997) and Schwartz (1997) find that in addition to taking senior positions, banks collateralize a high percentage of their loan portfolio.

Once the strong firm reaches its bank debt capacity, it is optimal to raise more debt capital through the flotation of market debt. Market debt complements bank debt, providing tax shield benefits beyond those attainable with bank debt only. However, the existence of market debt distorts the private workout process, with market lenders capturing some of the benefit attributable to bank concessions. Since the firm and bank fail to internalize this benefit, the workout process is abandoned prematurely, with bankruptcy costs being incurred. At the optimal debt structure, marginal bankruptcy costs associated with market debt are equated with marginal tax benefits, as in a standard trade-off model such as in Leland (1994). However, the presence of bank debt raises the marginal bankruptcy cost schedule, lowering the optimal market debt coupon.

Contractual priority is closely adhered to in countries with "tough" bankruptcy procedures, such as Britain and Germany. However, absolute priority (AP) violations are common in the U.S., where the bankruptcy procedure is "soft." 3 We extend our analysis of the strong firm, analyzing the effect of anticipated AP violations during the formal bankruptcy process. Such AP violations lower bank debt capacity, forcing the firm to substitute market debt. Therefore, trade-off theory predicts that the percentage of market debt will be higher (lower) in countries in which the bankruptcy regime is soft (tough). Consistent with this prediction, Rajan and Zingales (1995) find that market debt constitutes $25 \%$ of total debt in the U.S. In Germany, market debt amounts to less than $1 \%$ of total debt. Britain represents an intermediate case, with market debt equal to $4.4 \%$ of total debt.

At the end of our article, we analyze optimal debt structure for a weak firm. A weak firm receives take-it or leave-it offers from the bank in the

${ }^{3}$ See White (1996) for a discussion of bankruptcy law in the U.S. and Europe. 
event of a private workout: in contrast with the strong firm case, the bank holds all bilateral bargaining power ex post. The weak firm model best approximates small/young corporations. ${ }^{4}$ Trade-off theory predicts that a weak firm will rely exclusively on a bank for debt capital. That is, for weak firms, bank debt dominates any mix of market and bank debt regardless of the priority structure. This result contradicts the notion that small/young firms avoid public debt because they lack access to such markets or face prohibitive costs in so doing. Our model shows that even when a weak firm can tap public debt markets with fair pricing, doing so is suboptimal. The intuition is as follows. Within the trade-off theory, there is a debt "pecking-order" with bank debt being preferred to market debt because of the lower implied bankruptcy costs. When the bank holds all ex post bargaining power, the desired level of debt tax shields can be achieved using only bank debt. Consistent with this prediction, Blackwell and Kidwell (1988) document that small firms issue privately placed debt almost exclusively. In contrast, they find that larger firms are more likely to issue market debt.

The remainder of the article is organized as follows. Section 1 contains a review of related research. Sections 2 through 6 present the benchmark model, which assumes the firm holds all bargaining power during the private workout process. Section 3 derives claim values assuming the bank debt is senior. Section 4 derives claim values assuming the bank debt is junior. Section 5 endogenizes the total value received by creditors in the event of formal bankruptcy. Section 6 evaluates the effect of AP violations on debt structure. Section 7 derives optimal debt structure for the weak firm, where the bank holds all bargaining power during the private workout process. Concluding remarks and potential extensions of the model are provided in Section 8.

\section{Review of Related Literature}

In order to clarify the contributions of our article, Table 1 summarizes the features of related structural trade-off models. In the table, an entry of $Y$ generally implies that the model endogenizes or incorporates a feature that increases realism.

The first column details which articles allow for some form of debt renegotiation. Anderson and Sundaresan (1996) introduce strategic debt service using a binomial tree extensive form game. Mella-Barral (1999) and Hege and Mella-Barral (HMB) $(2000,2005)$ allow for repeated irreversible coupon concessions. Francois and Morellec (2004) model the Chapter 11 process, rather than a private workout. In particular, legal costs are

\footnotetext{
4 This is consistent with the motivation in Rajan (1992).
} 


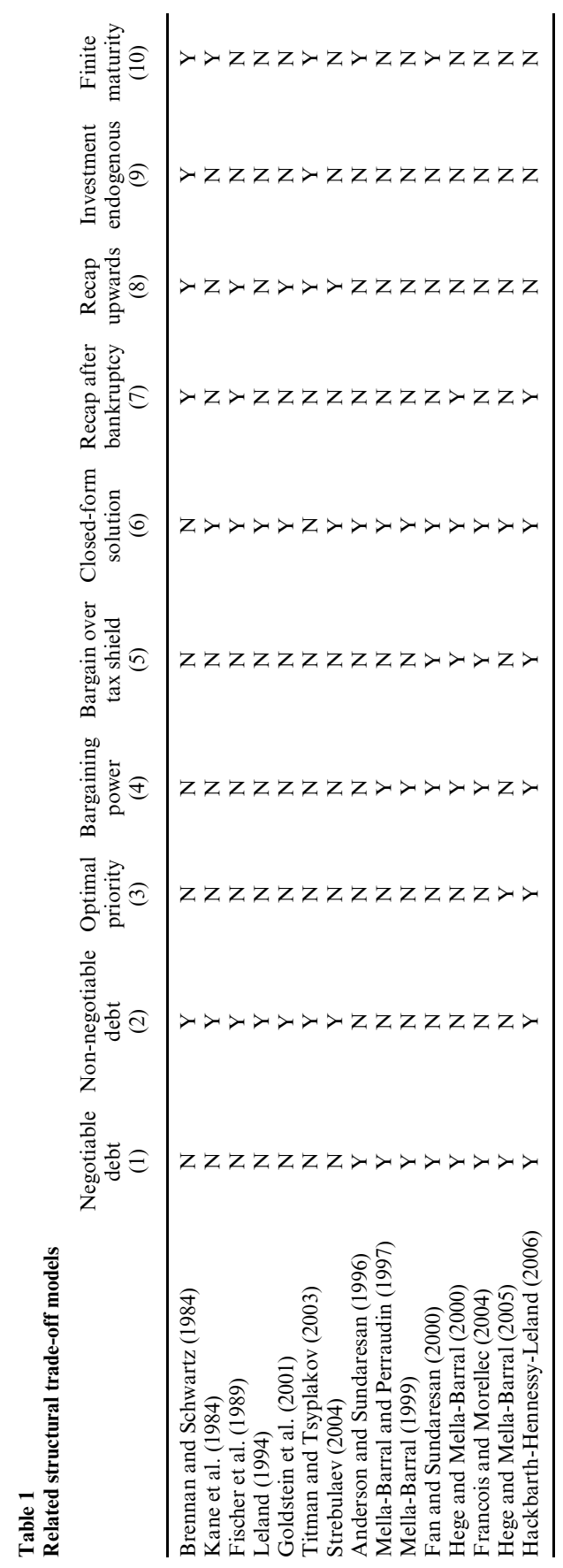

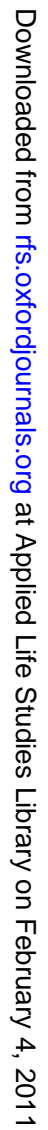


incurred and the bankruptcy court imposes liquidation if the firm does not recover within an observation window. Mella-Barral and Perraudin (1997) and Fan and Sundaresan (2000) assume the lender grants temporary statecontingent interest rate concessions in a costless private workout. Fan and Sundaresan employ Nash's (1953) axiomatic bargaining solution. Our modeling approach is most similar to that employed by Mella-Barral and Perraudin (1997), who consider a strategic game with take-it or leave-it offers between the firm and a single lender. ${ }^{5}$

One of the main results obtained by Mella-Barral and Perraudin (1997) is that, with a single bank lender, ex post renegotiation eliminates inefficient bankruptcy. We show that the presence of market debt distorts bilateral bargaining, inducing inefficient bankruptcy. This is because the two parties to the bargaining process, the bank and the firm, fail to internalize the positive externality accruing to market lenders when the bank grants interest rate concessions. Gertner and Scharfstein (1991) present a related bilateral contracting model between the firm and a bank lender. In their model, the presence of market debt leads to underinvestment in safe projects and overinvestment in riskier projects.

Houston and James (1996), Johnson (1997), Krishnaswami et al. (1999), and Denis and Mihov (2003) all find that the percentage of market debt in total debt is increasing in firm size and age. A key objective of our analysis is to determine whether the trade-off theory can be reconciled with this empirical evidence. As shown in the first and second columns of Table 1, existing structural trade-off models assume the firm issues either non-negotiable or negotiable debt. Consequently, these articles provide no obvious predictions regarding the optimal debt mix.

Our article is most closely related to that by HMB (2005). As shown in the table, their article is unique in that it also considers optimal priority. In their model, priority is allocated among market debt lenders, rather than between market lenders and the bank, as in our model. ${ }^{6}$ HMB go on to evaluate the choice between bank and market debt, although the choice is assumed to be mutually exclusive. Consequently, the HMB model does not provide predictions regarding optimal priority structure in a mixed debt firm. In their market debt model, interest rate concessions are possible. Atomistic lenders make coupon concessions in exchange for collateral rights. In this setting, the optimal debt contract withholds all liquidation rights at date zero, keeping them in reserve in order to induce future coupon concessions. In contrast, our model predicts that priority will be allocated to a bank lender ex ante. In the HMB model, debt capacity is

\footnotetext{
5 Davydenko and Strebulaev (2005) find credit spreads are influenced by strategic concerns. Of particular relevance for our analysis is their finding that credit spreads are larger when debt is private and/or the debt structure is simple.

${ }^{6}$ See also the dissertation of Fan (1997).
} 
higher with market debt, but comes at the cost of inefficient liquidation. Consequently, in their model, bank debt is optimal when the liquidation value of the firm is high. In contrast, we predict that bank debt is optimal when the firm is young/small.

The articles in the upper half of Table 1 are necessarily silent on the effect of bargaining power. Most models with negotiable debt analyze the role of bargaining power. Our article is the first to analyze the effect of bargaining power on optimal debt mix. In order to provide a more complete picture, the remaining columns of the table provide details regarding additional features of existing structural trade-off models.

The theory of optimal debt structure is the subject of an enormous contracting literature that abstracts from taxation. The reader is referred to Harris and Raviv (1991) and Hart (1995) for surveys. Within this literature, our trade-off model is most closely related to models based on ex post "hold-up." For example, Hart and Moore (1994) analyze a private firm with no access to public equity markets, i.e. the "entrepreneur" has limited wealth. In order to finance what is assumed to be a positive NPV project, the entrepreneur must raise the funds from an outside investor such as the local bank. Cash flows are nonverifiable, and the entrepreneur can extract concessions from the lender by threatening to withdraw his human capital from the project. ${ }^{7}$ In order to minimize the hold-up problem, the bank is given priority in the event of liquidation. Berglöf and von Thadden (1994) consider a wealth constrained entrepreneur in a setting with nonverifiable cash flows, allowing for multiple lenders. They show that if liquidation values are low, the optimal contracts entail a strict separation between the short-term and long-term lenders, with the short-term (bank) lender given seniority. This debt structure maximizes the bank's willingness to liquidate the project, which has the effect of increasing debt capacity. ${ }^{8}$

The similarity between the contracting models cited above and our tradeoff model lies in the fact that priority is used to increase the reservation value of the bank. The essential difference between the models is the rationale for why the firm wants to do so. The contracting models consider a small closely held firm that is unable or unwilling to tap outside equity. Inability to raise adequate funds threatens the firm's ability to pay a fixed investment cost. The optimal debt structure in such models maximizes the total amount of debt financing that can be obtained. The trade-off theory considers a large public corporation that is free to finance projects with outside equity. Therefore, the motivation for toughening the bank lender is not the relaxation of a financing constraint. Rather, the corporation wants to maximize bank debt capacity since this is the dominant source

\footnotetext{
${ }^{7}$ In our model, costs of formal bankruptcy play a similar role to valuable entrepreneurial skill. Both drive a wedge between the value of the firm in the hands of current management versus value to the lender(s).

${ }^{8}$ Repullo and Suarez (1998) present a related model with moral hazard.
} 
Table 2

Notation index

\begin{tabular}{rll}
\hline $\mathrm{X}$ & $\equiv$ & EBIT generated by project \\
$r$ & $\equiv$ & risk-free rate of interest on taxable bond \\
$(\mu, \sigma)$ & $\equiv$ & drift/volatility EBIT \\
$\mathrm{I}$ & $\equiv$ & cost of project \\
$\phi$ & $\equiv$ & proportional transactions cost on all external funds \\
$\theta$ & $\equiv$ & equity stake sold to new shareholders \\
$\tau$ & $\equiv$ & effective tax shield value using Miller (1977) \\
$v$ & $\equiv$ & value of levered firm $E+B+C$ \\
$\xi$ & $\equiv$ & deadweight bankruptcy cost parameter \\
$\Lambda$ & $\equiv$ & multiplier for recapitalized firm value \\
$U$ & $\equiv$ & multiplier for unlevered firm value \\
$E$ & $\equiv$ & equity value \\
$B$ & $\equiv$ & bank debt value \\
$b$ & $\equiv$ & coupon on bank debt \\
$C$ & $\equiv$ & market debt value \\
$c$ & $\equiv$ & coupon on bank debt \\
$X_{e}$ & $\equiv$ & equity's endogenous bankruptcy threshold (strong firm) \\
$X_{n}$ & $\equiv$ & renegotiation threshold chosen by equity \\
$T B$ & $\equiv$ & value of corporate tax shield \\
$B C$ & $\equiv$ & value of bankruptcy costs \\
$\mathbf{S}$ & $\equiv$ & set of admissible strategic debt service functions \\
$R$ & $\equiv$ & bank's reservation value in renegotiations \\
$\eta$ & $\equiv$ & contractual percent of bankruptcy value going to bank \\
$\widetilde{\eta}$ & $\equiv$ & actual percent of bankruptcy value going to bank \\
$\widehat{S}$ & $\equiv$ & incentive compatible debt service function \\
$v_{M}$ & $\equiv$ & value of levered firm constrained to market debt \\
$v_{B}$ & $\equiv$ & value of levered firm constrained to bank debt \\
$X_{b}$ & $\equiv$ & bank's endogenous bankruptcy threshold (weak firm) \\
$\mathbf{E}$ & $\equiv$ & expectations operator \\
$\mathbf{T}$ & $\equiv$ & set of stopping times under natural filtration \\
& & \\
\hline &
\end{tabular}

of external funds - outside equity is tax-disadvantaged, while market debt creates bankruptcy costs.

\section{The Model}

\subsection{Economic environment}

Table 2 contains a notation index. We make standard assumptions about the nature of uncertainty. There exists a complete probability space $(\Omega, \mathcal{F}, \mathcal{P})$ supporting a Wiener process $W_{t}$. For each time $t \in[0, \infty)$ information revelation is described by the filtration $\mathcal{F}_{t} \subset \mathcal{F}$, where each $\mathcal{F}_{t}$ is the augmented $\sigma$-algebra generated by the Wiener process. The underlying state variable $X$ is the EBIT generated by a nondepreciating "machine." For simplicity, we assume that EBIT uncertainty is purely idiosyncratic, so that the physical measure corresponds to the pricing measure. ${ }^{9}$ The initial value of EBIT is $X_{0}>0$ with the process evolving as follows

$$
\frac{d X}{X}=\mu d t+\sigma d W_{t} .
$$

9 This is without loss of generality. Goldstein et al. (2001) derive the correct adjustment to the physical drift in an equilibrium framework in which the representative agent has power utility. 
The EBIT-generating machine is the only investment available to the firm, there are no assets in place, and the corporation has no cash on hand. There is no option to delay the investment. In order to purchase the machine, the corporation must raise the investment cost $I$ from external sources. Note, we are considering a firm that is "cash constrained" in the sense that the investment cost exceeds internal funds. Thus, our model yields predictions regarding how much debt and equity corporations will issue in order to fill their "financing gaps." This exercise is distinct from modeling the dynamic behavior of leverage ratios. ${ }^{10}$

The firm may issue two classes of perpetual debt: bank debt, with promised flow coupon $b$, and market debt with promised flow coupon $c$. The value function for the bank debt is denoted $B$ and that for the market debt is denoted $C$. The total value of the firm's equity is denoted $E$. We place all sources of external finance on equal footing by assuming that each faces the same proportional flotation cost, denoted $\phi \in(0,1)$. Let $\theta \in[0,1)$ denote the equity stake that is sold to new shareholders. The funding condition is

$$
I=(1-\phi)\left[B\left(X_{0} ; b, c\right)+C\left(X_{0} ; b, c\right)+\theta E\left(X_{0} ; b, c\right)\right] .
$$

Trade-off theory abstracts from agency conflicts between the CEO and current shareholders, and from information asymmetries. The objective of the CEO is to maximize the value of the equity stake held by current shareholders. From Equation (1) it follows that the objective function can be stated as

$$
(1-\theta) E\left(X_{0} ; b, c\right)=E\left(X_{0} ; b, c\right)+B\left(X_{0} ; b, c\right)+C\left(X_{0} ; b, c\right)-\frac{I}{1-\phi} .
$$

From Equation (2), we see that maximizing the value of the equity stake of current shareholders coincides with maximizing the total value of the firm $(v)$, where

$$
v\left(X_{0} ; b, c\right) \equiv E\left(X_{0} ; b, c\right)+B\left(X_{0} ; b, c\right)+C\left(X_{0} ; b, c\right) .
$$

We denote the optimal financing policy as $\left(b^{*}, c^{*}\right)$, where

$$
\left(b^{*}, c^{*}\right) \in \arg \max _{b, c} v\left(X_{0} ; b, c\right) .
$$

Following Bulow and Shoven (1978) and Gertner and Scharfstein (1991), we assume that payments to market lenders cannot be changed

${ }^{10}$ See Hennessy and Whited (2005) for a model of leverage ratios under endogenous cash retentions and real investment over time. 
outside the formal bankruptcy process. ${ }^{11}$ There are three rationales for this assumption. First, with widely dispersed creditors, coordination costs may be prohibitive. Second, atomistic lenders have an incentive to free-ride off the concessions made by others. Finally, most countries impose stringent voting requirements for changing the terms of market debt outside the formal bankruptcy process. ${ }^{12}$ Gilson et al. (1990) and Asquith et al. (1994) provide empirical support for this modeling approach, finding that the existence of market debt is the most significant factor limiting the success of private workouts.

In contrast, the bank may grant state-contingent interest rate concessions in the course of a costless private workout. ${ }^{13}$ This is the only difference between market and bank debt in our model. Our benchmark model assumes equity holds full bargaining power, making take-it or leave-it offers to the bank. Section 7 analyzes optimal debt structure for the weak firm, where the bank makes take-it or leave-it offers.

Interest income is taxed at rate $\tau_{i}$. It is assumed that the EBIT drift $\mu$ is less than the after-tax return on a safe government bond, which is $r\left(1-\tau_{i}\right)$. There is a linear tax at rate $\tau_{c}$ on corporate income with full loss offset provisions. Cash distributions to shareholders are taxed at rate $\tau_{d}$. This stylized tax system is identical to that considered by Goldstein et al. (2001) and Strebulaev (2004).

Anticipating, we will value the levered firm $(v \equiv E+B+C)$ by comparing it with an otherwise equivalent unlevered firm. It is easily verified that the unlevered firm value is $U X$ where

$$
U \equiv \frac{\left(1-\tau_{d}\right)\left(1-\tau_{c}\right)}{r\left(1-\tau_{i}\right)-\mu}
$$

In the event of bankruptcy, debts are restructured so as to maximize the total value of marketable claims on the firm. Our benchmark model assumes that AP will be obeyed during the formal bankruptcy process. Section 6 relaxes this assumption.

Assumption 1. In the event of a bankruptcy reorganization, creditors split the total value of an optimally recapitalized firm, equal to $\Lambda X$ where $\Lambda \in(0, U)$. Absolute priority is obeyed during the formal bankruptcy process.

${ }^{11}$ Gertner and Scharfstein (1991) present a second model in which market debt is restructured through an exchange offer.

${ }^{12}$ For example, see Smith and Warner (1979) who discuss the Trust Indenture Act applicable to market debt in the U.S.

13 This is a private debt restructuring, not a default. By construction, the bank has no incentive to declare the firm as being in default. Moody's (2000) writes, "By their nature, bank loans are a private contract between the borrower and the lending institution." Moody's uses the date of default on market debt as the measure of a "default event." 
For the purpose of the analytical results, it is convenient to think of $\Lambda$ as some constant meeting Assumption 1. All parties treat this constant as common knowledge. For arbitrary $\Lambda<U$, Proposition 1 derives the optimal priority structure and debt coupons, with the latter being expressed in terms of $\Lambda$. The numerical analyses performed in Sections 5 and 6 compute $\Lambda$ endogenously. As in Hege and Mella-Barral (2000), we allow the creditors, who become the new owners of the firm, to optimally recapitalize once the firm enters the costly formal bankruptcy process. To capture the full value of future debt tax shields, we allow for an infinite sequence of downward recapitalizations by the successive owners. In order to account for bankruptcy costs, the numerical analysis assumes that EBIT is scaled down by a percentage $\xi$ each time the firm enters formal bankruptcy. Of course, the equilibrium value of $\Lambda$ will depend upon all exogenous parameters, including $\xi$. The assumption that $\Lambda<U$ holds when $\xi$ is sufficiently high.

The firm does not engage in upward recapitalizations of the project. An upward restructuring involves issuing debt in order to finance a special dividend to shareholders. In the Appendix it is shown that an upward levered recapitalization is not profitable if

$$
\phi>\frac{\tau_{c}-\tau_{i}}{1-\tau_{i}}
$$

The tax rate estimates in Graham (2000) suggest that most firms would be roughly indifferent to an upward leveraged recapitalization. Using detailed microsimulations, Graham estimated that from 1980 to 1994 the mean expected marginal corporate income tax rate was $31.5 \%$ based on earnings before interest. This estimate may overstate the current corporate tax shield value, since his sample includes the period 1980-1986, when the maximum corporate tax rate was $46 \%$. Graham estimated $\tau_{i}=29.6 \%$ in 1993 . On the basis of the evidence in Graham, our numerical results assume the following tax rate structure: $\tau_{c}=31 \%, \tau_{i}=30 \%$, and $\tau_{d}=10 \% .{ }^{14}$ Under these assumptions, the firm will not engage in upward restructuring if $\phi$ exceeds $1.43 \%$.

In the interest of brevity, it is convenient to introduce the following notation for the Miller (1977) tax shield value, which will play a role in our derivations

$$
\tau \equiv\left[1-\frac{\left(1-\tau_{d}\right)\left(1-\tau_{c}\right)}{\left(1-\tau_{i}\right)}\right] .
$$

We now invoke Assumption 2.

${ }^{14}$ Graham estimated the effective tax rate on equity income at the shareholder level to be $12 \%$. This tax rate reflects observed tax-inefficient payout policies. 
Assumption 2. Proportional transactions costs satisfy $\phi>\left(\tau_{c}-\tau_{i}\right) /(1-$ $\left.\tau_{i}\right)$. The tax shield parameter $\tau$ in Equation (6) is strictly positive.

The first part of the assumption guarantees that the firm will never choose to engage in an upward levered recapitalization. ${ }^{15}$ The second part of the assumption guarantees that there is a gross tax advantage of debt over external equity. Of course, the tax gain from debt must be weighed against bankruptcy costs.

\subsection{Valuation of contingent claims}

Consider an arbitrary time-homogeneous claim paying $m X+k$ after all taxes. The value function $(G)$ for the claim must satisfy the following ordinary differential equation (ODE) in equilibrium

$$
r\left(1-\tau_{i}\right) G(X)=m X+k+\mu X G^{\prime}(X)+\frac{1}{2} \sigma^{2} X^{2} G^{\prime \prime}(X) .
$$

The right side of the equation above represents the sum of the aftertax "dividend" plus the expected capital gain, with the latter computed according to Ito's lemma. The condition states that the expected instantaneous holding return must equal the after-tax return on the safe asset. The general solution to this ODE is

$$
G(X)=K_{1} X^{a}+K_{2} X^{z}+\frac{m X}{r\left(1-\tau_{i}\right)-\mu}+\frac{k}{r\left(1-\tau_{i}\right)},
$$

where $a<0$ and $z>1$ denote the roots of the quadratic

$$
Q(\zeta) \equiv \frac{1}{2} \sigma^{2} \zeta^{2}+\left(\mu-\frac{1}{2} \sigma^{2}\right) \zeta-r\left(1-\tau_{i}\right)=0 .
$$

All contingent claims priced below have solutions of this form, with suitable boundary conditions pinning down unknown constants.

Next consider a primary claim paying a dollar at the first passage (from above) of $X$ to some threshold $X^{*}$. On the basis of (7), it may be verified that for $X \geq X^{*}$, this claim's value is

$$
\text { Hitting Claim Value }=\left(\frac{X}{X^{*}}\right)^{a} \text {. }
$$

This claim value will be utilized frequently below.

Let $s(\cdot) \leq b$ denote instantaneous interest payments made to the bank. The sum of after-tax cash flows to shareholders, market lenders, and the

\footnotetext{
15 For lower transactions costs, upward restructuring would be optimal. Upward restructuring could be incorporated in the analysis in a manner similar to Goldsten et al. (2001), but at the cost of considerable additional complexity.
} 
bank is equal to

Total After-Tax Cash Flow

$$
=X\left(1-\tau_{c}\right)\left(1-\tau_{d}\right)+[c+s(X)]\left[\tau_{c}+\left(1-\tau_{c}\right) \tau_{d}-\tau_{i}\right] .
$$

It follows from Assumption 2 that the last bracketed term in Equation (9) is strictly positive. The levered firm value is unlevered firm value plus the value of the debt tax shield less the value of bankruptcy costs.

$$
v(X)=U X+T B(X)-B C(X) .
$$

Let $X_{e}$ denote the firm's endogenous bankruptcy threshold. As shown in Equation (9), the levered firm has higher after-tax cash flows than the unlevered firm prior to bankruptcy. The value of the increase in total after-tax cash flows is simply $\tau$ multiplied by the expected discounted value of coupons prior to bankruptcy

$$
T B(X)=\tau\left[B(X)+C(X)-\Lambda X_{e}\left(\frac{X}{X_{e}}\right)^{a}\right] .
$$

We next place a price on the value differential between the unlevered and levered firm at the time of bankruptcy. This value differential is the bankruptcy cost

$$
B C(X)=(U-\Lambda) X_{e}\left(\frac{X}{X_{e}}\right)^{a}
$$

It follows that

$$
v(X)=U X+\tau\left[B(X)+C(X)-\Lambda X_{e}\left(\frac{X}{X_{e}}\right)^{a}\right]-(U-\Lambda) X_{e}\left(\frac{X}{X_{e}}\right)^{a} .
$$

Equation (13) is an alternative expression for the objective function of the CEO, clarifying the fundamental trade-off between tax shields and bankruptcy costs.

\subsection{Strategic debt service}

This subsection characterizes the general features of strategic debt service when the firm is strong, that is, has the ability to make take-it or leave-it offers to the bank during private workouts. This analysis will be relevant for Sections 3-6.

To motivate the argument, consider a one-shot bargaining game in which a strong party makes a take-it or leave-it offer to a weak party regarding how to split a pie of size $\Pi>0$. Suppose that the weak party has an outside option (reservation value) paying $R<\Pi$ in the event that 
he rejects the offer. The equilibrium entails the strong party offering $R$ and the weak party accepting.

The benchmark model of Sections 3-6 features a similar bargaining setting. The firm is strong and has the ability to make take-it or leave-it offers to the bank regarding debt service. If the bank rejects the offer, formal bankruptcy proceedings are initiated. The bank's payoff in the event of formal bankruptcy is denoted $R(\cdot)$. We will say that $R$ represents the bank's reservation value function, since the bank would reject any debt service offer yielding a lower payoff than $R$.

The bank's reservation value depends on $\operatorname{EBIT}(X)$ and the debt priority structure. For example, suppose that at date $t$ the firm comes to the bank offering $s\left(X_{t}\right)<b$. In considering this offer, the bank determines what it would receive if it were to reject the offer and induce bankruptcy. The total value of the reorganized firm is $\Lambda X_{t}$, with the bank's portion determined by its position in the priority structure.

In the event of a private workout, debt service offers must be sufficient to induce acceptance by the bank. We confine attention to debt service functions that are piecewise right-continuous in $X$. Consequently, the debt service function must be chosen from the following set $\mathbf{S}$

$$
\mathbf{S} \equiv\{s: s \text { is piecewise right-continuous and } s(X)<b \Rightarrow B(X) \geq R(X)\} .
$$

Intuitively, any debt service function in the set $\mathbf{S}$ has the property that when the payment to the bank is less than the promised coupon, the value of the claim held by the bank if it chooses to accept $(B)$ is weakly greater than the value it would receive in bankruptcy $(R)$.

As the informal discussion above suggests, optimal strategic debt service pushes the bank down to its reservation value whenever renegotiation occurs. This is stated formally as Lemma $1 .{ }^{16}$

Lemma 1. If the debt service function s is optimal for the firm, then $s(X)<b$ implies $B(X)=R(X)$.

Proof. Suppose to the contrary $\exists X$ such that $s(X)<b$ and $B(X)>R(X)$. Then $\exists \widetilde{s} \in \mathbf{S}$, such that $\widetilde{s}<s$ on a set of nonzero measure about $X$ and $\widetilde{s}=s$ elsewhere. Equity value is higher under $\widetilde{s}$ than under $s$, contradicting optimality of $s$.

\section{Senior Bank Debt}

Sections 3 and 4 derive optimal priority under the benchmark assumption that the firm can make take-it or leave-it debt service offers to the bank.

16 This result is stated as Proposition 4 in Mella-Barral and Perraudin (1997). 
The present section analyzes senior bank debt, and the next junior bank debt. Anticipating, we demonstrate that a strong firm optimally uses a mixture of bank and market debt, with the bank placed senior.

In subsection 3.2, we derive the firm value $(v)$ obtained when only market debt is issued. For $b>0$, the basic solution method is to conjecture an equilibrium in which some form of debt renegotiation takes place. We then derive total firm value $(v)$ under such equilibria. For some coupon pairs $(b, c)$, renegotiation would not take place in equilibrium. In such cases, it is easily verified that total firm value is identical to the value achieved by issuing market debt exclusively with coupon $\widetilde{c}=b+c$. Since they are redundant from a total firm value perspective, below we ignore mixed debt policies that do not entail some form of renegotiation.

\subsection{Strategic Debt Service with Linear Sharing}

If the bank is senior, its reservation value is determined by

$$
\text { Bank Senior }: R(X)=\min \left\{\frac{b}{r}, \Lambda X\right\} \text {. }
$$

For the purpose of generality, in this subsection we consider a priority structure that is described by the parameter $\eta \in(0,1]$. The parameter $\eta$ represents the percentage of the restructured firm value $(\Lambda X)$ that would be paid to the bank in the event that formal bankruptcy proceedings were initiated. The market lenders would receive the remaining value $(1-\eta) \Lambda X$.

The valuation implications of senior bank debt (15) are captured by setting $\eta=1$ in this linear sharing model. The reasoning is as follows. For pairs $(b, c)$ such that there is renegotiation, under senior bank debt it must be the case that for any $X$ on the renegotiation region

$$
R(X)=\Lambda X<\frac{b}{r}
$$

If the "less than" sign above were not satisfied, the bank would reject any debt service offer less than $b$. Therefore, setting $\eta=1$ accurately reflects the bank's reservation value (15) during renegotiations. Consequently, the linear sharing model with $\eta=1$ gives the correct strategic debt service $s$ and claim valuations for senior bank debt.

In the linear sharing model, equity chooses an optimal bankruptcy threshold $\left(X_{e}\right)$, as well as the instantaneous debt service paid to the bank. Let $\mathbf{T}$ denote the set of all stopping times under the augmented filtration. The equity value function is

$$
E(X)=\left(1-\tau_{d}\right)\left(1-\tau_{c}\right) \sup _{s \in \mathbf{S}, T \in \mathbf{T}} \mathbf{E}_{0}\left[\int_{0}^{T} e^{-r\left(1-\tau_{i}\right) t}\left[X_{t}-c-s\left(X_{t}\right)\right] d t\right] .
$$


We now characterize strategic debt service assuming the debt structure, as characterized by the triple $(b, c, \eta)$, is such that renegotiation occurs. The incentive compatible strategic debt service function is denoted $\widehat{s}$. In our model, there exists a single threshold denoted $X_{n}$ at which the firm will initiate renegotiations. There exists an interval $\left[X_{n}, \infty\right)$ such that no renegotiation occurs and $\widehat{s}(X)=b$. From Lemma 1 we know that optimal strategic debt service pushes the bank down to its reservation value $\eta \Lambda X$ on an endogenous region $\left(X_{e}, X_{n}\right)$ over which renegotiation occurs.

On the basis of Equation (7), the function $B$ must satisfy the following ODE in nonbankruptcy states

$$
r\left(1-\tau_{i}\right) B(X)=\left(1-\tau_{i}\right) \widehat{s}(X)+\mu X B^{\prime}(X)+\frac{1}{2} \sigma^{2} X^{2} B^{\prime \prime}(X) .
$$

Substituting $B(X)=\eta \Lambda X$ into Equation (18) allows us to identify the flow of debt payments that will be made in the event of a private workout

$$
\widehat{s}(X)=\left[r-\mu /\left(1-\tau_{i}\right)\right] \eta \Lambda X .
$$

Equation (19) is informative about the role of priority structure. When the bank is high in priority, the ex post hold-up problem is mitigated since debt service in renegotiation states is increasing in $\eta$. In fact, priority has a two-fold effect. It is shown below that the renegotiation threshold $\left(X_{n}\right)$ is decreasing in $\eta$. Intuitively, high priority for the bank implies that equity must pay more in order to successfully complete a private workout. Recognizing this fact, equity will be less anxious to enter into renegotiations when $\eta$ is high. In addition, we show below that bank debt capacity increases with $\eta$.

In choosing when to enter into a private workout, equity finds the highest value of $X$ such that the offer given in Equation (19) would be accepted by the bank. Technically, this reduces the optimal renegotiation strategy to a smooth-pasting problem. Let the subscripts $L$ and $H$ denote claim values for $X \in\left[X_{e}, X_{n}\right)$ and $X \geq X_{n}$, respectively. The bank debt value function is given by ${ }^{17}$

$$
\begin{aligned}
& B_{L}(X)=\eta \Lambda X \quad \forall X \in\left[X_{e}, X_{n}\right) \\
& B_{H}(X)=A_{1} X^{a}+A_{2} X^{z}+\frac{b}{r} \forall X \in\left[X_{n}, \infty\right) .
\end{aligned}
$$

The unknowns for this problem are $\left(A_{1}, A_{2}, X_{n}\right)$, which are derived using value matching, smooth-pasting, and an asymptotic condition

$$
B_{H}\left(X_{n}\right)=\eta \Lambda X_{n},
$$

${ }^{17}$ In the case of no bankruptcy, the term $X_{e}$ is replaced with zero. 


$$
\begin{aligned}
& \frac{\partial B_{H}\left(X_{n}\right)}{\partial X}=\eta \Lambda, \\
& \lim _{X \rightarrow \infty} B_{H}(X)=\frac{b}{r} .
\end{aligned}
$$

These conditions yield the following bank debt values and renegotiation threshold

$$
\begin{aligned}
B_{H}(X) & =\frac{b}{r}-\left(\frac{b}{r}-\eta \Lambda X_{n}\right)\left(\frac{X}{X_{n}}\right)^{a} \\
X_{n} & =\frac{b}{r}\left(\frac{a}{a-1}\right)\left(\frac{1}{\eta \Lambda}\right) .
\end{aligned}
$$

Figure 1(A) plots strategic debt service when the bank is senior. One might be tempted to conclude that the firm will want to renegotiate for all values of $X$ such that the expression given in (19) is less than $b$. Under such a policy, $\widehat{s}$ would be continuous. However, this debt service function does not belong to the feasible set $\mathbf{S}$. Under the proposed policy, the value of bank debt would fall below the reservation value in the left neighborhood of $X_{n}$ and the bank would opt for formal bankruptcy. In fact, the debt service function must exhibit a jump at the point $X_{n}$, since

$$
\lim _{X \uparrow X_{n}} \widehat{s}\left(X_{n}\right)=\left(\frac{r-\mu /\left(1-\tau_{i}\right)}{r}\right)\left(\frac{a}{a-1}\right) b<b .
$$

Figure 1(B) plots the corresponding dividends to equity when the bank is senior. The dividend is nonmonotonic. As $X$ falls, the dividend exhibits an upward jump at $X_{n}$. The upward jump reflects the debt service concessions made by the bank when the private workout is initiated. Note also that shareholders begin injecting cash into the firm as $X$ converges to $X_{e}$. Up to a point, shareholders will be willing to contribute funds to the firm in order to keep alive their option on positive cash flows. Negative dividends are a generic feature of models with endogenous default.

Figure 2 plots the value of senior bank debt under alternative assumptions regarding $\xi$, and with it, $\Lambda$. Ceteris paribus, the value of the reorganized firm $(\Lambda X)$ is low when bankruptcy costs $(\xi)$ are high. The bank's value function $(B)$ pastes smoothly to its reservation value function $(R)$ at the renegotiation threshold $\left(X_{n}\right)$. When $\Lambda$ is low, the bank has a low reservation value. This reduces debt service in renegotiation states and causes equity to enter into renegotiations sooner. This is because $X_{n}$ is higher when $\Lambda$ is low. This effect can be seen in Figure 2. 

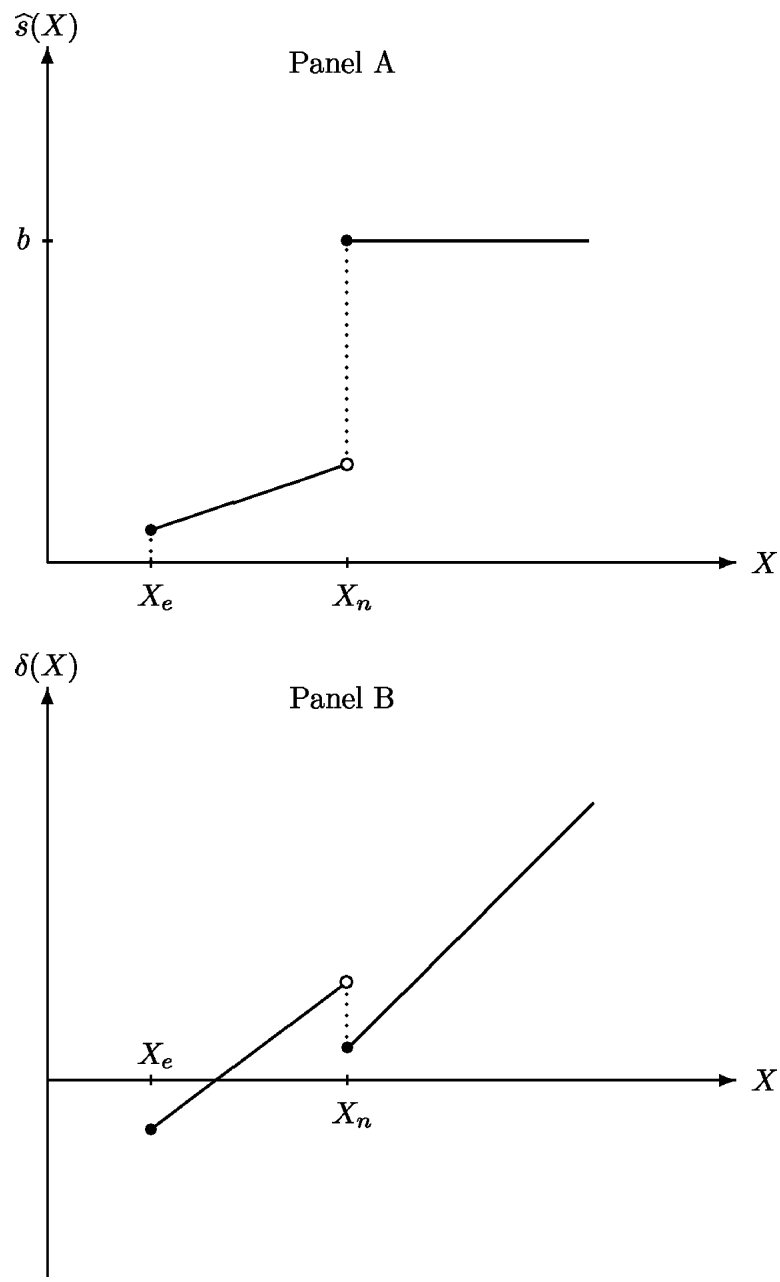

Figure 1

Strategic debt service and dividends in case of senior bank debt

Strategic debt service $\widehat{s}(X)$ and dividends $\delta(X)$ of the strong firm as a function of EBIT $X$ in case of Senior Bank Debt $B$ with promised coupon $b>0$. It is assumed that there is Market Debt $C$ with promised coupon $c>0$ outstanding.

The value function for market debt satisfies (7) with the flow payment equal to $c\left(1-\tau_{i}\right)$. The boundary conditions are value matching at bankruptcy and an asymptotic condition

$$
\begin{aligned}
C\left(X_{e}\right) & =(1-\eta) \Lambda X_{e}, \\
\lim _{X \rightarrow \infty} C(X) & =\frac{c}{r} .
\end{aligned}
$$




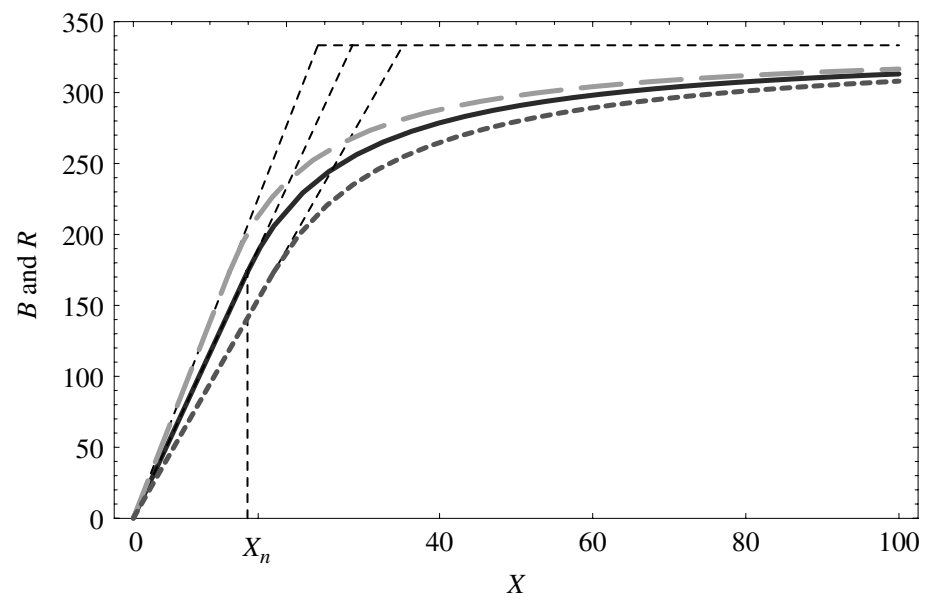

Figure 2

Senior bank debt and bank's reservation value

Senior Bank Debt $B$ and bank's reservation value $R$ for a strong firm as a function of EBIT $X$ for a given coupon level $b$ as the firm's bankruptcy costs and hence the recapitalized firm value multiplier vary: $\Lambda=0.71 U$ (long dashed line), $\Lambda=0.60 U$ (solid line), and $\Lambda=0.49 U$ (short-dashed line). It is assumed that $X_{0}=20, b=20, r=6 \%, \mu=1 \%, \sigma=25 \%, \tau_{c}=31 \%, \tau_{d}=10 \%, \tau_{i}=30 \%$, and $\eta=1$.

The solution for the value of market debt under linear sharing is

$$
C(X)=\frac{c}{r}\left[1-\left(\frac{X}{X_{e}}\right)^{a}\right]+(1-\eta)\left(\Lambda X_{e}\right)\left(\frac{X}{X_{e}}\right)^{a} .
$$

With each of the terms in the levered firm value expression (10) in hand, the value of equity can be expressed as the residual of firm value less total debt value

$$
E(X)=U *\left[X-X_{e}\left(\frac{X}{X_{e}}\right)^{a}\right]-(1-\tau)\left[B(X)+C(X)-\Lambda X_{e}\left(\frac{X}{X_{e}}\right)^{a}\right] .
$$

The remaining unknown is the endogenous bankruptcy threshold. This is derived using a smooth-pasting condition

$$
\frac{\partial E\left(X_{e}\right)}{\partial X}=0
$$

The default threshold under linear sharing is

$$
X_{e}(b, c)=\left(\frac{a}{a-1}\right)\left(\frac{(1-\tau) c / r}{U-\eta(1-\tau) \Lambda}\right) .
$$

When the bank is senior, and AP is obeyed, the correct claim values are obtained by setting $\eta=1$ in all of the formulas derived in this subsection. 
The results of this subsection for $\eta<1$ will be used in Section 6, when we evaluate the effect of AP violations during the formal bankruptcy process.

\subsection{Exclusive market debt finance}

In order to contrast with our results on the optimal mix of bank and market debt, we consider first the optimal coupon for a firm constrained to issue market debt exclusively. For the purpose of clarity, the functions $v_{M}$ and $v_{B}$ denote levered firm values for firms constrained to issue only market debt or only bank debt, respectively. Substituting Equation (23) into the levered firm value expression (10) and dropping terms involving bank debt we have the following objective function ${ }^{18}$

$$
v_{M}\left(X_{0} ; c\right)=U X_{0}+\frac{\tau c}{r}\left[1-\left(\frac{X_{0}}{X_{e}}\right)^{a}\right]-(U-\Lambda) X_{e}\left(\frac{X_{0}}{X_{e}}\right)^{a} .
$$

Expression (26) simplifies to

$$
X_{e}(0, c)=\left(\frac{a}{a-1}\right)\left(\frac{(1-\tau) c / r}{U}\right) .
$$

The optimal coupon satisfies the first-order condition $\partial v_{M}\left(X_{0} ; c_{M}^{*}\right) / \partial c=$ 0 , implying

$$
c_{M}^{*}\left(X_{0}\right)=\left(\frac{a-1}{a}\right)\left(\frac{r U}{1-\tau}\right)\left[\frac{\tau}{\tau-a[1-(1-\tau)(\Lambda / U)]}\right]^{(-1 / a)} X_{0} .
$$

Substituting this expression back into the levered firm value expression yields the value of the optimally levered firm financing with market debt exclusively

$$
v_{M}\left(X_{0} ; c_{M}^{*}\right)=U X_{0}\left(1+\left(\frac{\tau}{1-\tau}\right)\left[\frac{\tau}{\tau-a[1-(1-\tau)(\Lambda / U)]}\right]^{(-1 / a)}\right) .
$$

The arch in the foreground of Figure 3 depicts the function $v_{M}\left(X_{0} ; \cdot\right)$. An interior optimum market debt coupon is clearly present. The other points in the figure represent mixed debt pairs, with senior bank debt. We discuss the optimal mixed debt policy in the next subsection.

\subsection{Optimal debt mix when bank is senior}

We now derive optimal coupons when the bank is senior. For this purpose, we use the claim values in subsection 3.1 with $\eta=1$. The optimal coupons under the mixed debt policy maximize total levered firm value. The

${ }^{18}$ Similar expressions are derived by Leland (1994). In his model $V$ corresponds to our $U X$ and his bankruptcy cost parameter $\alpha$ corresponds to $(U-\Lambda) / U$ in our model. 


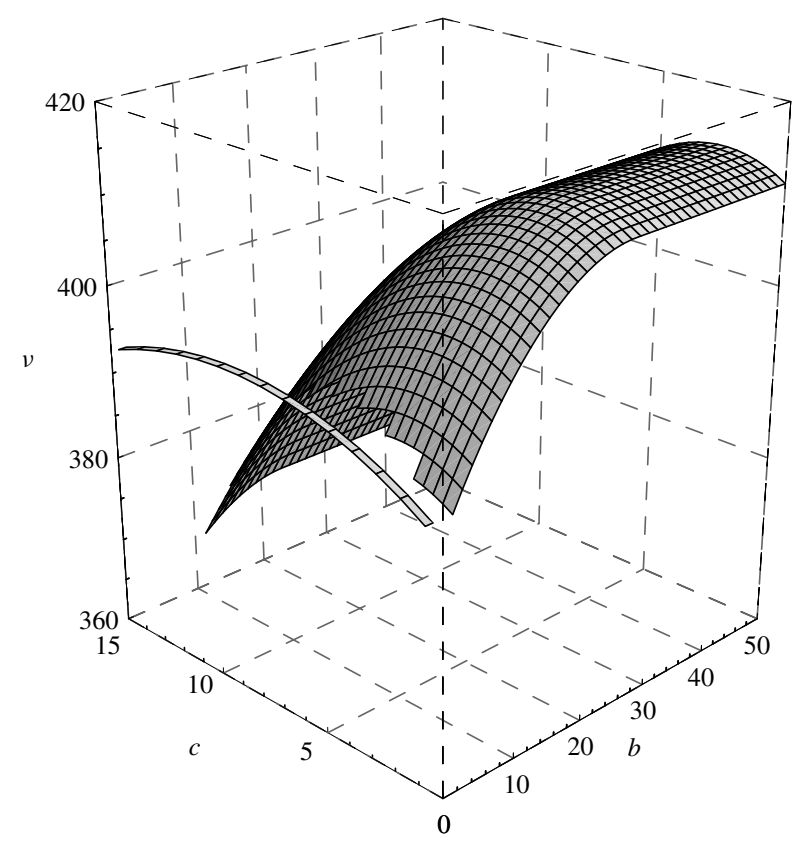

Figure 3

Total value of mixed debt firm

Total firm value $v$ as a function promised coupon payments to the bank $b$ and to the market $c$ when equity holders have all the bargaining power vis-à-vis the bank and the bank debt is senior $(\eta=1)$. It is assumed that $X_{0}=20, r=6 \%, \mu=1 \%, \sigma=25 \%, \xi=50 \%, \tau_{c}=31 \%, \tau_{d}=10 \%$, and $\tau_{i}=30 \%$, which implies that the unlevered firm value equals $U X_{0}=\left(1-\tau_{c}\right)\left(1-\tau_{d}\right) X_{0} /\left[r\left(1-\tau_{i}\right)-\mu\right]=388.13$. The maximized levered firm value is $v\left(b^{*}, c^{*}\right)=413.49$, where $b^{*}=25.06$ and $c^{*}=2.49$.

objective function is

$$
\begin{aligned}
\max _{(b, c)} v\left(X_{0} ; b, c\right)= & U X_{0}+\tau\left[B\left(X_{0}\right)+C\left(X_{0}\right)-\Lambda X_{e}\left(\frac{X_{0}}{X_{e}}\right)^{a}\right] \\
& -(U-\Lambda) X_{e}\left(\frac{X_{0}}{X_{e}}\right)^{a}
\end{aligned}
$$

and the bankruptcy threshold is given by

$$
X_{e}(b, c)=\left(\frac{a}{a-1}\right)\left(\frac{(1-\tau) c / r}{U-(1-\tau) \Lambda}\right) .
$$

Rearranging terms, the maximand may be restated as

$$
\begin{aligned}
\max _{(b, c)} v\left(X_{0} ; b, c\right)= & U X_{0}+\tau C\left(X_{0}\right)-U X_{e}[1-(1-\tau)(\Lambda / U)] \\
& \times\left(\frac{X_{0}}{X_{e}}\right)^{a}+\tau B\left(X_{0}\right) .
\end{aligned}
$$


Note that the maximization problem is separable in $b$ and $c$, since the first three terms do not depend on $b$, while the last term does not depend on $c$. Apparently, the optimal value of $b$ is that which maximizes the value of the bank debt. That is, the optimal debt mix (conditional on the bank being senior) entails issuing bank debt up to the firm's bank debt capacity. ${ }^{19}$

The intuition for bank debt capacity is as follows. From Equation (21) it can be seen that the renegotiation threshold $\left(X_{n}\right)$ increases monotonically in $b$. Low levels of $b$ are consistent with $X_{0}>X_{n}(b)$. However, for all coupons such that $X_{n}(b) \geq X_{0}$, the bank recognizes that the instant after the debt contract has been signed, equity will propose a renegotiation. The bank knows that in this renegotiation it will be pushed down to its reservation value $\Lambda X_{0}$. Therefore, the initial value of bank debt cannot exceed $\Lambda X_{0}$.

There exists a critical coupon, denoted $b^{\max }$, such that further increasing the promised coupon cannot raise the value of bank debt. More formally, $b^{\max }$ satisfies

$$
X_{n}\left(b^{\max }\right)=X_{0} .
$$

Using condition (21) it follows that

$$
b^{*}=b^{\max }=\left(\frac{a-1}{a}\right) r \Lambda X_{0} .
$$

Next, we pin down the optimal coupon on market debt. Differentiating (33) with respect to $c$ and rearranging the first-order condition yields

$$
c^{*}\left(X_{0}\right)=\left(\frac{a-1}{a}\right)\left(\frac{r U}{1-\tau}\right)\left[\frac{\tau}{\tau-a}\right]^{(-1 / a)}[1-(1-\tau)(\Lambda / U)] X_{0} .
$$

Comparison of Equations (36) and (29) reveals that the optimal market debt coupon is lower for the mixed debt firm. This is because under the mixed debt policy, the marginal bankruptcy cost of market debt is higher. The root cause is that the mixed debt firm enters bankruptcy sooner. This can be seen from inspection of the respective default thresholds in Equations (28) and (32).

Substituting the optimal coupons into the levered firm value equation, we have

$$
v\left(X_{0} ; b^{*}, c^{*}\right)=U X_{0}\left[1+\tau \Lambda / U+\left(\frac{\tau}{1-\tau}\right)\left(\frac{\tau}{\tau-a}\right)^{(-1 / a)}[1-(1-\tau)(\Lambda / U)]\right] .
$$

\footnotetext{
${ }^{19}$ Below it is shown that the qualifier is not necessary. That is, the strong firm always levers up to its bank debt capacity.
} 
Equation (37) identifies the sources of value created by the mixed debt policy. Consider first the value of the (strong) firm constrained to raise debt capital from bank debt. From Equation (32) we know that such a firm never enters formal bankruptcy. ${ }^{20}$ From Equation (33) it follows that the constrained $(c=0)$ optimal policy again calls for levering up to the firm's bank debt capacity. Therefore, total levered firm value under pure bank debt finance is equal to

$$
v_{B}\left(X_{0} ; b_{B}^{*}\right)=U X_{0}[1+\tau \Lambda / U] .
$$

The value increase from being able to mix market and (senior) bank debt is

$$
\begin{aligned}
& v\left(X_{0} ; b^{*}, c^{*}\right)-v_{B}\left(X_{0} ; b_{B}^{*}\right) \\
& \quad=U X_{0}\left(\frac{\tau}{1-\tau}\right)\left(\frac{\tau}{\tau-a}\right)^{(-1 / a)}[1-(1-\tau)(\Lambda / U)]>0 .
\end{aligned}
$$

This is a key result, to which we will return in the proof of Proposition 1. In particular, we have established that if the bank is senior, the mixed debt firm is worth strictly more than the firm that is only able to access bank debt. The strong firm will issue bank debt until it hits the capacity constraint, and thereafter issue a strictly positive amount of market debt.

\section{The suboptimality of junior bank debt}

As in Section 3, we maintain the working assumption that the firm is strong, and can make take-it or leave-it offers to the bank. The linear sharing rule discussed above does not subsume the case of junior bank debt. The reservation value of the bank in this case is determined by

$$
\text { Bank Junior } \Rightarrow R(X)=\min \left\{\frac{b}{r}, \max \left\{0, \Lambda X-\frac{c}{r}\right\}\right\} \text {. }
$$

In this section we characterize equilibria for junior bank debt under the assumption that there is a region of debt renegotiation. For any coupon pair $(b, c)$ such that there is no renegotiation, the analysis is identical to that under exclusive market debt finance with promised coupon $\tilde{c}=b+c$.

\subsection{Strategic Debt Service when the Bank is Junior}

Once again, the function $\widehat{s}$ denotes the incentive compatible bank debt service function for equity. There exists an interval $\left[X_{n}, \infty\right)$ such that no renegotiation occurs with $\widehat{s}(X)=b$. As shown in Lemma 1, an optimal strategic debt service schedule must push the bank down to its reservation

\footnotetext{
20 This is a special case of the Coase Theorem. See also Proposition 3 in Mella-Barral and Perraudin (1997).
} 
value on the renegotiation region $\left(X_{e}, X_{n}\right)$. That is, on the renegotiation region $B$ is equal to $R$, where $R$ is given in Equation (40).

If $\Lambda X>c / r$, the bank knows that it will receive some value in the event of default even though it is junior. Therefore, on some left neighborhood of the renegotiation threshold $\left(X_{n}\right)$, we know $R(X)=\Lambda X-c / r$. Substituting $R$ and its derivatives into Equation (18) allows us to compute strategic debt service for intermediate values of $X$

$$
\widehat{s}(X)=\left[r-\mu /\left(1-\tau_{i}\right)\right] \Lambda X-c .
$$

Consider next the threshold

$$
X_{\ell} \equiv \frac{c}{r \Lambda} .
$$

When $X<X_{\ell}, \Lambda X<c / r$ and the bank knows that it will receive nothing in the event of bankruptcy. From Lemma 1 we know $B(X)=R(X)=0$ on this region. Substituting $R$ and its derivatives into Equation (18) we find that $\widehat{s}(X)=0$ on this region.

When the bank is junior, we can summarize strategic debt service as follows

$$
\widehat{s}(X)=\left\{\begin{array}{ll}
b & \forall X \in\left[X_{n}, \infty\right) \\
{\left[r-\mu /\left(1-\tau_{i}\right)\right] \Lambda X-c} & \forall X \in\left[X_{\ell}, X_{n}\right) \\
0 & \forall X \in\left[X_{e}, X_{\ell}\right)
\end{array} .\right.
$$

Strategic debt service for junior bank debt is depicted in Figure 4(A). Comparing Equation (19) with Equation (41), we see that for the strong firm, placing the bank junior results in a downward shift in amount $c .^{21}$ In other words, debt service on market debt crowds out debt service on bank debt dollar for dollar. It can also be verified that:

$$
\widehat{s}\left(X_{\ell}\right)=\frac{-\mu c}{r\left(1-\tau_{i}\right)}<0 .
$$

Equation (44) shows that a bank placed junior in the priority structure will "bail out" the firm in bad states. Evaluated at the point $X_{\ell}$, the bail-outs provided by the bank in the right-neighborhood of $X_{\ell}$ are just equal in value to the bank's claim on positive cash flows if the firm mounts a substantial recovery. Hence, we have $B(X)=0$ for all $X \in\left[X_{e}, X_{\ell}\right]$.

Anticipating, such bail-outs will never occur in equilibrium in our model, since it will never be optimal to place the bank junior. However, the analysis above is instructive in that it offers a plausible explanation regarding

21 The interest rate concessions when the bank is junior are more substantial than when it is senior. Such concessions are more likely to be viewed as a "significant modification" of the debt instrument. This could trigger cancellation of debt income. We ignore this possibility, showing that junior bank debt is dominated even when granted generous tax treatment. 

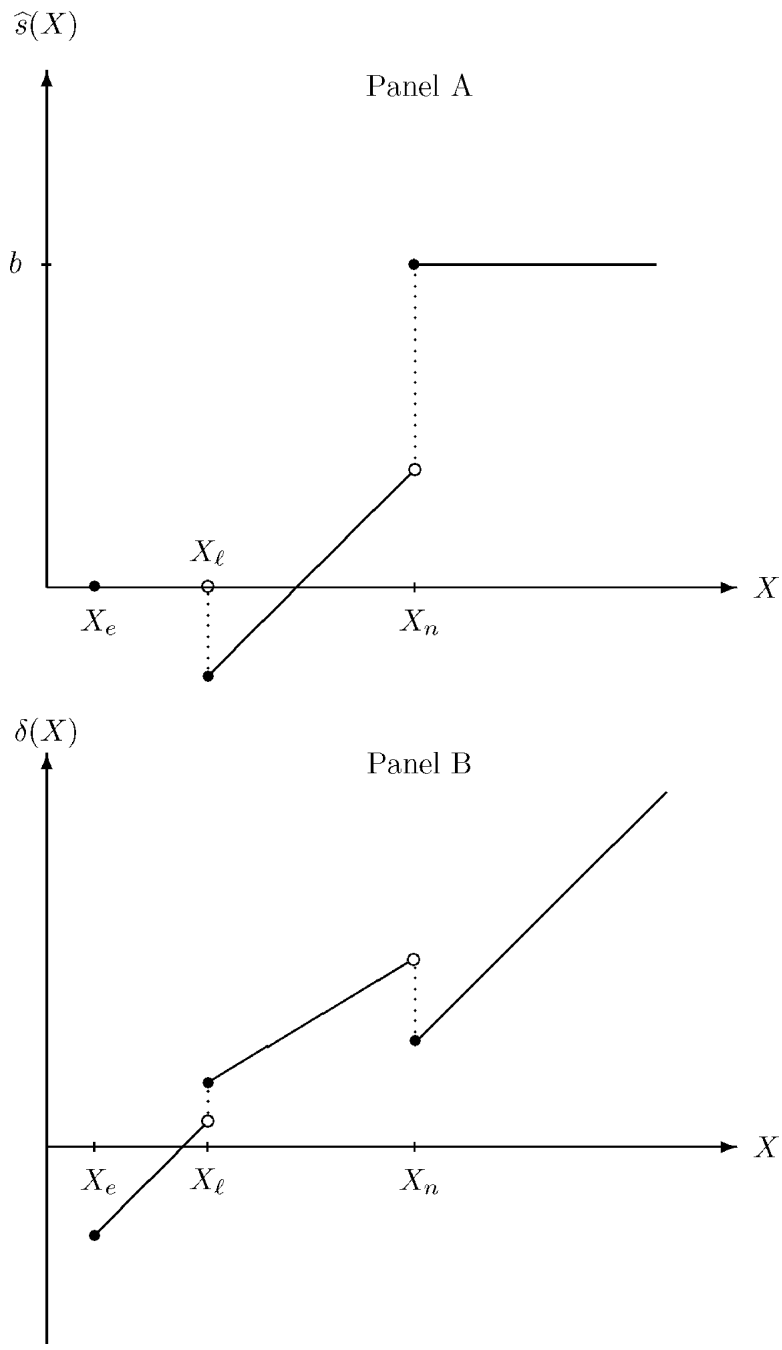

\section{Figure 4}

Strategic debt service and dividends in case of junior bank debt

Strategic debt service $\widehat{s}(X)$ and dividends $\delta(X)$ of the strong firm as a function of EBIT $X$ in case of Junior Bank Debt $B$ with promised coupon $b>0$. It is assumed that there is Market Debt $C$ with promised coupon $c>0$ outstanding.

why banks desire seniority. Banks cannot commit themselves against renegotiating. In fact, the ability to renegotiate is a factor commonly cited as making bank loans special. However, our model shows that placing a bank junior in priority leaves it especially vulnerable to being held-up ex post. 
Figure 4(B) depicts the dividends paid to shareholders when the bank is placed junior. It is interesting to contrast this figure with Figure 1(B), which depicted dividends when the bank is senior. When the bank is junior, the dividend payment is nonmonotonic. Now, the dividend function exhibits two jumps. As $X$ falls, the dividend jumps upward when the firm initiates renegotiations at $X_{n}$. As depicted, the dividend is strictly positive on the region $\left[X_{\ell}, X_{n}\right)$. Once $X_{\ell}$ is reached, the dividend jumps down, reflecting the fact that the bank is unwilling to contribute additional funds. The shareholders of the firm make up the funding gap, injecting funds into the firm until the endogenous default threshold is reached.

The following lemma and corollary are implied by the endogenous debt service function described above:

Lemma 2. For the strong firm issuing junior bank debt, in any equilibrium with renegotiation, the bankruptcy threshold satisfies

$$
X_{e}(b, c)<X_{\ell}(c) \text {. }
$$

Proof. Inspection of the $\widehat{s}$ function implies that cash flow to equity on the region $\left[X_{\ell}, X_{n}\right)$ is

$$
\left(1-\tau_{d}\right)\left(1-\tau_{c}\right)\left[1-\left(\frac{\left(1-\tau_{d}\right)\left(1-\tau_{c}\right)}{\left(1-\tau_{i}\right)}\right) \frac{\Lambda}{U}\right] X>0 .
$$

Since this is strictly positive, choosing to enter the formal bankruptcy process on this region cannot be an optimal policy for equity since bankruptcy pays zero.

Corollary 1. For the strong firm placing the bank junior, in any equilibrium with renegotiation the market lenders collect the entire value $\Lambda X_{e}$ in the event of bankruptcy.

Proof. Lemma 2 shows that $X_{e}<X_{\ell}$, which implies $\Lambda X_{e}<c / r$. Under AP, the bank receives zero.

In choosing its renegotiation threshold, equity finds the highest possible value of $X$ such that the offer given in Equation (43) will be accepted by the bank in the left neighborhood of $X_{n}$. Technically, this reduces the optimal renegotiation strategy to a smooth-pasting problem.

The junior bank debt value function is given by

$$
\begin{aligned}
B_{L}(X) & =0 & & \forall X \in\left[X_{e}, X_{\ell}\right) \\
B_{M}(X) & =\Lambda X-\frac{c}{r} & & \forall X \in\left[X_{\ell}, X_{n}\right) \\
B_{H}(X) & =A_{3} X^{a}+A_{4} X^{z}+\frac{b}{r} & & \forall X \in\left[X_{n}, \infty\right)
\end{aligned} .
$$

The remaining unknowns $\left(A_{3}, A_{4}, X_{n}\right)$ are derived using the following boundary conditions, which represent value matching, smooth-pasting, 
and asymptotic conditions, respectively

$$
\begin{gathered}
B_{H}\left(X_{n}\right)=\Lambda X_{n}-\frac{c}{r}, \\
\frac{\partial B_{H}\left(X_{n}\right)}{\partial X}=\Lambda, \\
\lim _{X \rightarrow \infty} B_{H}(X)=\frac{b}{r} .
\end{gathered}
$$

This yields the following bank debt value and renegotiation threshold ${ }^{22}$

$$
\begin{gathered}
B_{H}(X)=\frac{b}{r}\left[1-\left(\frac{1}{1-a}\right)\left(\frac{X}{X_{n}}\right)^{a}\right]-\frac{c}{r}\left(\frac{1}{1-a}\right)\left(\frac{X}{X_{n}}\right)^{a} \\
X_{n}=\left(\frac{b+c}{r}\right)\left(\frac{a}{a-1}\right)\left(\frac{1}{\Lambda}\right) .
\end{gathered}
$$

Comparison of Equations (21) and (47) shows that for a given coupon pair $(b, c)$, renegotiation occurs sooner (at a higher EBIT level) under junior bank debt than under senior bank debt. This is because placing the bank junior erodes its reservation value in the event of renegotiations.

The valuation formulas for the tax shield and bankruptcy costs are as given in Equations (11) and (12), respectively. Equity is once again valued as the residual of total firm value over total debt value. Further, the corollary indicates that market debt lenders recover the full amount $\Lambda X_{e}$ in the event of bankruptcy. Therefore, the market debt value function is

$$
C(X)=\frac{c}{r}\left[1-\left(\frac{X}{X_{e}}\right)^{a}\right]+\Lambda X_{e}\left(\frac{X}{X_{e}}\right)^{a} .
$$

Using the smooth-pasting condition (25), we can derive the bankruptcy threshold

$$
X_{e}(b, c)=\left(\frac{a}{a-1}\right)\left(\frac{(1-\tau) c / r}{U}\right) .
$$

Comparison of Equations (28), (32) and (49) reveals some interesting insights. Suppose we hold fixed the market debt coupon at some amount $c$. It can be seen that the default threshold for the firm with only market debt is the same as the default threshold for the firm that has also issued junior bank debt. This is because equity value is the residual of firm value over market and bank debt values. When the bank debt is junior, it is

\footnotetext{
${ }^{22}$ In order for the posited equilibrium to be valid, it must be the case that $X_{\ell}<X_{n}$. A sufficient condition is $c<-a b$.
} 
worth zero once $X$ is sufficiently low. Consequently, junior bank debt does not affect the default threshold. In contrast, the firm with senior bank debt adopts a higher default threshold, reflecting the fact that a senior bank receives strictly positive cash flows and holds a claim that has strictly positive value.

\subsection{Optimal debt mix when bank is junior}

Substituting in the pricing equation for market debt (48), the total levered firm value expression (31) simplifies as follows

$$
\begin{aligned}
v\left(X_{0} ; b, c\right)= & U X_{0}+\left(\frac{\tau c}{r}\right)\left[1-\left(\frac{X_{0}}{X_{e}}\right)^{a}\right] \\
& -(U-\Lambda) X_{e}\left(\frac{X_{0}}{X_{e}}\right)^{a}+\tau B\left(X_{0} ; b, c\right)
\end{aligned}
$$

The optimal coupons can be derived using a two step procedure. We first solve for the optimal bank debt coupon for an arbitrary $c$. We then optimize over $c$.

Pick an arbitrary $c>0$. Note that each of the first three terms in the maximand is independent of $b$. Therefore, it must be the case that:

$$
b^{*}(c) \in \arg \max _{b} B\left(X_{0} ; b, c\right)
$$

The optimal junior bank debt coupon commitment, for a given $c$, entails the firm being at its bank debt capacity. Using the same logic as in Section 3, it must be the case that

$$
X_{n}\left[b^{*}(c), c\right]=X_{0} \Leftrightarrow b^{*}(c)=\left(\frac{a-1}{a}\right) r \Lambda X_{0}-c .
$$

Since the optimal bank debt coupon entails being at bank debt capacity, it follows that

$$
B\left[X_{0} ; b^{*}(c), c\right]=\Lambda X_{0}-\frac{c}{r} .
$$

The formula above illustrates the crowding-out effect of market debt when the bank is placed junior in priority.

Substituting Equation (53) into Equation (50) yields the following objective function in $c$

$$
\max _{c}[1+\tau(\Lambda / U)] U X_{0}-\left[\frac{\tau c}{r}+(U-\Lambda) X_{e}\right]\left(\frac{X_{0}}{X_{e}}\right)^{a}
$$

Lemma 3 follows directly from the fact that the objective in (54) is strictly declining in $c$. 
Lemma 3. If the strong firm is constrained to placing the bank junior, it is optimal to choose an arbitrarily small market debt coupon with the bank debt coupon set to

$$
b^{*}=\left(\frac{a-1}{a}\right) r \Lambda X_{0} .
$$

The intuition for Lemma 3 is as follows. When the bank is junior, there is a large indirect tax shield cost associated with issuing market debt, since market debt reduces bank debt capacity. In addition, issuance of market debt creates bankruptcy costs. The combination of these two costs is sufficient to swamp the direct tax shield benefit coming from market debt.

Proposition 1 is our main analytical result on debt structure.

Proposition 1. For the strong firm, the optimal debt structure entails a mix of bank and market debt, with the bank senior in priority. The optimal coupons are

$$
\begin{aligned}
& c^{*}\left(X_{0}\right)=\left[\frac{r U}{1-\tau}\right]\left[\frac{a-1}{a}\right]\left[\frac{\tau}{\tau-a}\right]^{(-1 / a)}[1-(1-\tau)(\Lambda / U)] X_{0} \\
& b^{*}\left(X_{0}\right)=\left(\frac{a-1}{a}\right) r \Lambda X_{0}
\end{aligned}
$$

and the total firm value is

$$
\begin{aligned}
& v\left(X_{0} ; b^{*}, c^{*}\right) \\
& \quad=U X_{0}\left[1+\tau \Lambda / U+\left(\frac{\tau}{1-\tau}\right) \frac{\tau}{\tau-a}^{(-1 / a)}[1-(1-\tau)(\Lambda / U)]\right] .
\end{aligned}
$$

Proof. From Lemma 3 we know that bona fide junior bank debt is strictly dominated by pure bank debt finance. The maximum firm value achieved under pure bank debt finance is $v_{B}\left(X_{0} ; b_{B}^{*}\right)$. From Equation (39), we know this value is strictly less than the value of the firm using the optimal mix of senior bank debt and junior market debt. The optimal coupon payments and firm value were derived in subsection 3.3.

\section{Restructuring in the Event of Bankruptcy}

This section explicitly models the debt restructuring process once the firm enters formal bankruptcy. We adopt the following assumptions regarding exogenous parameters: $\tau_{c}=31 \%, \tau_{i}=30 \%, \tau_{d}=10 \%, \sigma=0.25, \mu=$ 
$0.01, r=6 \%, \xi=50 \%$, and $X_{0}=20 .{ }^{23}$ Under this constellation of tax rates, the tax advantage of debt over external equity is $\tau=11.3 \%$.

We next recast Assumption 1 in terms of economic primitives.

Assumption 1'. In the event of bankruptcy, equity receives zero. The EBIT process is scaled down to $(1-\xi) X$. The firm is recapitalized optimally, with the bondholders dividing total firm value between them in accordance with $A P$.

The firm enters bankruptcy when EBIT hits the threshold $X_{e}<X_{0}$. At this point, the EBIT process scales down to $(1-\xi) X_{e}$. As was the case at date zero, the objective is to maximize the market value of claims on the firm, with the proceeds being distributed in accordance with AP. The only change in the maximization problem is that the firm has lower EBIT than at date zero. If the initial priority structure and coupon pair $\left(b_{0}^{*}, c_{0}^{*}\right)$ are indeed optimal, then the optimal policy calls for the firm to emerge from bankruptcy with the same priority structure with the coupons scaled down to

$$
\left(\frac{(1-\xi) X_{e}}{X_{0}}\right)\left(b_{0}^{*}, c_{0}^{*}\right)
$$

In order to compute the value of the firm for arbitrary coupon values, we exploit the scaling property inherent in the model. Consider a firm that issues a mix of senior bank debt and market debt, with the initial coupon pair $\left(b_{0}, c_{0}\right)$. Suppose that, in the event of default, the creditors simply scale down the coupons by the factor $(1-\xi) X_{e} / X_{0}$. The value recovered by lenders in the event of default would be:

$$
\left[\frac{(1-\xi) X_{e}\left(b_{0}, c_{0}\right)}{X_{0}}\right] * v\left(X_{0} ; b_{0}, c_{0}\right) \text {. }
$$

To compute total firm value (v), the term in Equation (56) takes the place of $\Lambda X_{e}$ in Equation (33), since it represents the true value recovered by lenders in default under the scaling policy. Solving the resulting recursive equation for $v$, we obtain an expression for the total value of a firm that implements scaled downward restructuring each time formal bankruptcy takes place:

$$
v\left(X_{0} ; b, c\right)=\frac{U\left[X_{0}-X_{e}\left(\frac{X_{0}}{X_{e}}\right)^{a}\right]+\tau\left[B\left(X_{0}\right)+C\left(X_{0}\right)\right]}{1-(1-\tau)(1-\xi)\left(\frac{X_{e}}{X_{0}}\right)\left(\frac{X_{0}}{X_{e}}\right)^{a}} .
$$

Figure 3 maps coupon pairs $(b, c)$ into firm values on the basis of Equation (57). The bank debt is senior, as is optimal. The hollow region of

23 The Mathematica code for the model is available from the authors upon request. 
the figure represents coupon pairs such that there would be no renegotiation of the bank debt. Such debt structures are economically equivalent to exclusive market debt finance with coupon $\tilde{c}=b+c$. Consistent with Proposition 1, there is an interior optimal market debt coupon, with $c^{*}=2.49$ and $C=36.68$. The bank debt coupon is consistent with reaching bank debt capacity, with $b^{*}=25.06$ and $B=205.53$. Thus, a total of 242.21 of external debt finance is obtained, with bank debt constituting $85 \%$ of that total.

The percentage of project finance obtained from external equity depends on the assumed project cost. At the optimal debt structure, the total value of equity is $E=171.28$. This value is split between the old and new shareholders, with the exact split depending on the investment cost $I$. Since financing is obtained on fair terms, existing shareholders capture the entire NPV from the project. If $I$ is sufficiently low, the project can be financed with $\theta=0$, with all external funds coming from debt. At the opposite extreme, we can find the value of $I$ such that the project has an NPV of zero. ${ }^{24}$ In this case, the total amount of external funds raised is 413.49 , with external equity constituting $41.4 \%$ of the total.

Thus, our model predicts that the majority of external finance will come from debt, with the percentage varying with the size of the financing gap. If the financing gap is large, the firm will use external equity as the marginal source of funds. These predictions are consistent with the stylized facts presented by Lemmon and Zender (2004) and Frank and Goyal (2005), who find that debt issuance closely tracks firms' financing gaps.

\section{Deviations from Absolute Priority during the Formal Bankruptcy Process}

In this section, we relax Assumption 1, which assumed that AP is obeyed during the formal bankruptcy process. At this point, it is important to distinguish between priority violations that occur outside formal bankruptcy versus those that occur during formal bankruptcy. In the analysis above, we allowed for deviations from priority in favor of equity during the private workout process. In particular, equity was allowed to retain its residual claim despite failing to deliver promised debt service to the bank. However, up to now we have maintained the working assumption that it is possible to commit to a particular division of value in the event of formal bankruptcy.

Franks and Torous (1994) provide some support for this modeling approach, finding that violations of priority are more pronounced in distressed exchanges than in Chapter 11 reorganizations. However, Franks and Torous $(1989,1994)$ and Weiss (1990) also document that deviations from AP are commonly observed during Chapter 11.

\footnotetext{
${ }^{24}$ When $I=v /(1-\phi)$, it follows that $\theta=1$ and the project has zero NPV to current shareholders.
} 
To date, the literature on AP violations has focused almost exclusively on the treatment of equity. ${ }^{25}$ The model by Welch (1997) is an important exception. In his model, it is optimal to place the bank senior in order to minimize "influence costs." Intuitively, putting the toughest bargainer senior is an effective device for deterring those attempting to influence the division of value. In this section, we address two related questions: (i) Should we expect to see different debt structures in countries that differ in the degree to which the courts adhere to AP across creditor classes? (ii) Is there a cost associated with violating AP during the formal bankruptcy process?

In Proposition 1, we showed that it is optimal for the strong firm to place the bank senior $\left(\eta^{*}=1\right)$ when the courts adhere to AP. An American bank may rationally anticipate that AP will be violated during the Chapter 11 process. To put some mathematical structure on the analysis, assume that the actual value split, call it $\widetilde{\eta}(\cdot)$, is a deterministic monotonic (increasing) function of the contractual splitting rule, which has been denoted as $\eta$. The optimal value of $\eta$ is still one in this setting, although debt structure will be affected.

As a thought experiment, consider three possible bankruptcy regimes: tough, medium and soft. Letting the subscript denote the bankruptcy regime, let us assume that

$$
\begin{gathered}
\widetilde{\eta}_{t}(1)=1 \\
\widetilde{\eta}_{m}(1)=\frac{3}{4} \\
\widetilde{\eta}_{s}(1)=\frac{1}{2} .
\end{gathered}
$$

In the tough regime, the senior position of the bank is inviolable. If the bank is promised $100 \%$ of the reorganized firm value, it receives this amount. A good example of such a regime is that found in Germany. The soft bankruptcy regime can be viewed as approximating Chapter 11. In the soft regime, the bank receives only half the reorganized firm value, despite the fact that it sits senior in priority.

Table 3 summarizes results on the effect of violations of AP across creditor classes. When the bankruptcy regime is tough, market debt only constitutes $15 \%$ of total debt. When the bankruptcy regime fails to ensure adherence to AP, two effects are present, both of which increase the relative importance of market debt. Relative to the tough bankruptcy regime, the amount of bank debt is reduced by roughly $25 \%$ and $50 \%$ for the medium and soft regimes, respectively. The second effect is that the firm increases the amount of market debt. Intuitively, lower values of $\tilde{\eta}$ allow the firm

\footnotetext{
${ }^{25}$ Bebchuk (2002) provides a survey of this literature.
} 
Table 3

Deviations from AP across creditor classes

\begin{tabular}{lccccc} 
Bankruptcy & \multicolumn{2}{c}{ Bank debt } & \multicolumn{2}{c}{ Market debt } & Project value \\
Regimes & $b^{*}$ & $B(X)$ & $c^{*}$ & $C(X)$ & $v(X)$ \\
\hline$\tilde{\eta}_{t}(1)=1$ & 25.06 & 205.53 & 2.49 & 36.68 & 413.49 \\
$\tilde{\eta}_{m}(1)=0.75$ & 18.79 & 152.64 & 3.72 & 54.25 & 408.60 \\
$\tilde{\eta}_{S}(1)=0.50$ & 12.53 & 100.77 & 5.14 & 74.11 & 403.99 \\
\hline
\end{tabular}

to pay the bank less during private workouts. This reduces marginal bankruptcy costs associated with market debt, since equity is willing to continue longer. This effect can be seen directly in the expression for the bankruptcy threshold (26), where $\tilde{\eta}$ would replace $\eta$. Under the medium bankruptcy regime, market debt becomes more important, increasing to $26 \%$ of total debt. Under the soft regime, market debt constitutes $42 \%$ of total debt.

As was stated in the introduction, Rajan and Zingales (1995) provide evidence supportive of these predictions. Within the G-7, bank debt as a percentage of total debt is higher in countries with tough bankruptcy regimes. Johnson (1997) provides firm-level evidence on debt structure within the U.S. In his sample, $36 \%$ of firms have some market debt. For those firms with some market debt, the mean (median) percentage of market in total debt is $34 \%(40 \%)$. Our model produces debt mix estimates consistent with these figures.

Our model also contributes new insights to the debate regarding costs and benefits of violations of AP. Leland (1994) considers the effect of violations of AP favoring equity during the formal bankruptcy process. He shows that such AP violations are value destroying. This is because AP violations in favor of equity cause the firm to default sooner, which increases bankruptcy costs. ${ }^{26}$ In the interest of logical clarity, we have ruled out violations of AP favoring equity during the formal bankruptcy process and focus instead on the costs of AP violations across creditor classes. ${ }^{27}$

Table 3 shows that violations of AP during the formal bankruptcy process are costly. For example, total ex ante project value can be increased by $2.35 \%$ if the formal bankruptcy regime switches from soft to tough. However, the model also indicates that violations of priority outside the formal bankruptcy process are beneficial. In particular, if the bank were unable to grant interest rate concessions outside the formal bankruptcy process, the debt mix would be irrelevant since there would be nothing special about bank debt. In this case the firm could simply optimize over

\footnotetext{
26 See equation (37) in Leland (1994).

27 Violations of AP during the formal bankruptcy process favoring equity would also destroy ex ante value in our model. Two effects would arise. First, bank debt capacity and tax shield value would decline. Second, bankruptcy costs would increase since the firm would default sooner.
} 
the amount of market debt and achieve a value of $v_{M}\left(X_{0} ; c_{M}^{*}\right)=395.49 .^{28}$ Relative to this value, total firm value increases by $4.55 \%$ under a regime that allows for bank flexibility in private workouts while adhering strictly to AP during the formal bankruptcy process.

\section{The Weak Firm}

As was the case in the strong firm model above, the weak firm has discretion regarding whether and when to initiate renegotiations. So long as the firm delivers the promised payment to the bank, there is no renegotiation. In the event that it initiates renegotiation, the weak firm has no bargaining power.

As a first step in the analysis, we characterize the bank debt service function for the weak firm. In the event that equity fails to pay the promised coupon and chooses to renegotiate, the bank has the ability to make a take-it or leave-it offer. In this situation, equity will be pushed down to its reservation value, which is zero under AP. Since equity value is everywhere zero on the renegotiation region, satisfaction of Equation (7) implies that the cash flow to equity is zero in renegotiation states. That is, in renegotiation states, equity delivers all cash flow, $X-c$, to the bank.

Equity chooses to enter into renegotiation at some endogenous threshold, denoted $X_{n}(b, c)$. So long as the bank is willing to cover the difference between $X$ and $c$, equity is just willing to continue and formal bankruptcy is avoided. Consequently, for the weak firm, it is the bank that effectively chooses when to initiate the formal bankruptcy process. The bank's endogenous bankruptcy threshold will be denoted $X_{b}(b, c)$. Figure 5(A) illustrates debt service for the weak firm and Figure 5(B) depicts the corresponding dividend payments. For high EBIT levels, the promised debt service is paid. In renegotiation states, all cash flow is delivered to the bank. When EBIT is sufficiently low relative to the market debt coupon, bankruptcy occurs.

Proposition 2 proves that the optimal debt policy for a weak firm entails exclusive bank debt. This result holds regardless of the assumed priority structure on any proposed mixed debt financing arrangement.

Proposition 2. For the weak firm, any coupon pair $(b, c)$ with $c>0$ is weakly dominated by exclusive bank debt finance with coupon $\bar{b}=b+c$.

Proof. See Appendix.

The intuition for Proposition 2 is as follows. For the weak firm, bank debt capacity is not a binding constraint. There is no need for the firm to issue market debt in order to obtain the desired level of debt tax

${ }^{28} \overline{\text { See equation }}(30)$. 

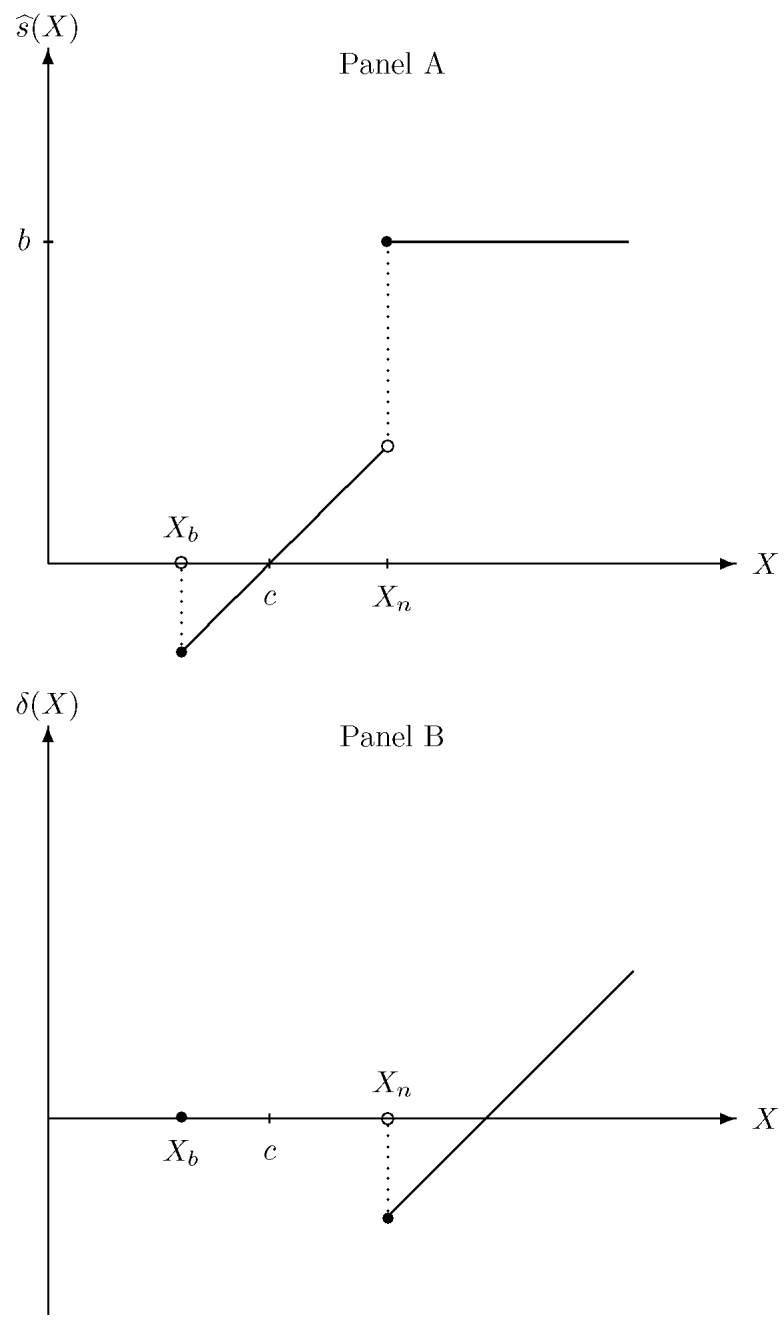

Figure 5

Strategic debt service and dividends in case of a weak firm

Strategic debt service $\widehat{s}(X)$ and dividends $\delta(X)$ of the weak firm as a function of EBIT $X$ in case of Bank Debt $B$ with promised coupon $b>0$. It is assumed that there is Market Debt $C$ with promised coupon $c>0$ outstanding.

shields. Market debt only serves to reduce firm value. This is because the existence of market debt results in premature bankruptcy. Intuitively, the two parties to the renegotiation process, equity and the bank, neglect the beneficial effect that postponement of bankruptcy proceedings might have on market lenders. 


\section{Conclusion}

This article demonstrates that the trade-off theory is sufficient to explain many stylized facts regarding corporate debt structure. The optimal debt structure for weak firms entails financing exclusively with bank debt. Strong firms optimally use a mix of bank and market debt, with the bank senior. The trade-off theory also generates predictions consistent with international evidence. In countries in which the bankruptcy regime entails soft (tough) enforcement of contractual priority, bank debt capacity is lower (higher), implying greater (lower) reliance on market debt.

The assumption of perpetual debt precludes discussion of optimal maturity structure, suggesting a natural direction for future research. However, given the underlying similarity between our model and the contracting model of Berglöf and von Thadden (1994), there is good reason to believe that such an extension would generate results consistent with the stylized facts. In particular, given that both models share the objective of increasing the bank's reservation value, it is likely that our model will share the prediction that short maturity bank debt is optimal.

It should also be noted that nothing in our analysis precludes alternative theories regarding the role of bank debt. Rather, the rich set of predictions generated by application of continuous-time methods to the trade-off theory suggests that further extension of structural pricing models will prove fruitful. The dividend is two-fold. First, we hope this article will convince others that structural pricing models have the potential to shed new light on the implications of existing theories. Second, incorporating a richer set of real-world factors, such as monitoring by intermediaries or reputational concerns, will improve the performance of structural pricing models in terms of predicting asset prices and credit spreads.

\section{Appendix A: Proof of Proposition 2}

Proposition 2 applies to the weak firm. Optimal debt policy maximizes the sum of equity plus debt values. Consider an arbitrary mixed debt policy $(b, c)$ and priority rule $(f)$ which maps $\Lambda X$ into bank recoveries. Any remaining value goes to the market lender. Now consider an alternative debt structure, with zero market debt, with the bank debt coupon set to $\bar{b} \equiv b+c$. Cash flow to shareholders outside the respective renegotiation regions is identical under both debt policies. Renegotiation gives equity a payoff of zero in either case. It follows that shareholders in the respective firms choose the same renegotiation thresholds

$$
X_{n}(b, c)=X_{n}(\bar{b}, 0),
$$

with the equity values in the two firms equal for all $X$. Thus, we must simply compare debt values across the two firms. 
The debt service function for the mixed debt firm is denoted $s$ with the corresponding bank and market debt values denoted $(B, C)$, respectively. Conversely, let $\bar{s}$ denote bank debt service and $\bar{B}$ the bank debt value for the firm using only bank debt. On the intersection of the respective continuation regions (regions in which bankruptcy does not occur)

$$
\bar{s}(X)=s(X)+c .
$$

The stopping time problem for the bank in the firm using only bank debt is

$$
\bar{B}\left(X_{0}\right) \equiv \max _{T \in \mathbf{T}} \mathbf{E}_{0}\left[\int_{0}^{T} e^{-r\left(1-\tau_{i}\right) t}\left[\bar{s}\left(X_{t}\right)\right] d t+e^{-r\left(1-\tau_{i}\right) T} \Lambda X_{T}\right] .
$$

The stopping time problem for the bank in the firm using mixed debt is

$$
B\left(X_{0}\right) \equiv \max _{T \in \mathbf{T}} \mathbf{E}_{0}\left[\int_{0}^{T} e^{-r\left(1-\tau_{i}\right) t}\left[s\left(X_{t}\right)\right] d t+e^{-r\left(1-\tau_{i}\right) T} f\left(\Lambda X_{T}\right)\right] .
$$

Let $T^{*}$ represent the optimal stopping time for the bank in the mixed debt firm. Using Equation (A2) and the fact that recoveries in default sum to $\Lambda X$, we have

$$
\left.B\left(X_{0}\right)+C\left(X_{0}\right)=\mathbf{E}_{0}\left[\int_{0}^{T^{*}} e^{-r\left(1-\tau_{i}\right) t} \bar{s}\left(X_{t}\right)\right] d t+e^{-r\left(1-\tau_{i}\right) T^{*}} \Lambda X_{T^{*}}\right] \leq \bar{B}\left(X_{0}\right) .
$$

\section{Appendix B: Necessary Condition for Tax Benefit to Upwards Recapitalizations}

For simplicity, consider an unconstrained firm that is considering the flotation of a safe bond with coupon $\delta$. The net proceeds from the bond issuance (after transactions costs) will be used to finance a dividend to shareholders. Of course, the debt service will force a reduction in future dividends to shareholders. So, the levered recap is a fly-now pay-later deal from their perspective. The bond sells for $\delta / r$, with shareholders receiving

$$
\left(1-\tau_{d}\right)(1-\phi) \frac{\delta}{r}
$$

The discounted value of the after-tax cost of servicing the debt is

$$
\frac{\delta\left(1-\tau_{c}\right)\left(1-\tau_{d}\right)}{r\left(1-\tau_{i}\right)}
$$




\section{The necessary condition for this being a positive NPV transaction is}

$$
\phi<\frac{\tau_{c}-\tau_{i}}{1-\tau_{i}}
$$

\section{References}

Anderson, R. W., and S. M. Sundaresan. 1996. The Design and Valuation of Debt Contracts. Review of Financial Studies 9:37-68.

Asquith, P., R. Gertner, and D. S. Scharfstein. 1994. The Anatomy of Financial Distress: An Examination of Junk Bond Issuers. Quarterly Journal Economics 109:625-58.

Bebchuk, L. A. 2002. Ex Ante Costs of Violating Absolute Priority in Bankruptcy. Journal of Finance $57: 445-60$.

Berglöf, E., and E. von Thadden. 1994. Short-term versus Long-Term Interests: Capital Structure with Multiple Investors. Quarterly Journal Economics 109:1055-84.

Blackwell, D., and D. Kidwell. 1988. An Investigation of Cost Differences between Public Sales and Private Placements of Debt. Journal of Financial Economics 22:253-78.

Brennan, M. J., and E. S. Schwartz. 1984. Optimal Financial Policy and Firm Valuation. Journal of Finance 39:593-607.

Bulow, J. I., and J. B. Shoven. 1978. The Bankruptcy Decision. Bell Journal of Economics 9:436-45.

Bulow, J. I., L. H. Summers, and V. P. Summers. 1990. Distinguishing Debt from Equity in the Junk Bond Era, in J. B. Shoven, and J. Waldfogel (eds), Debt, Taxes, and Corporate Restructuring. Washington, DC: The Brookings Institution.

Carey, M. 1995. Are Bank Loans Mispriced? Working Paper, Board of Governors of the Federal Reserve System.

Davydenko, S., and I. Strebulaev. 2005. Strategic Actions, Capital Structure, and Credit Spreads: An Empirical Investigation. Journal of Finance forthcoming.

Denis, D. J., and V. T. Mihov. 2003. The Choice among Bank Debt, Non-bank Private Debt, and Public Debt: Evidence from New Corporate Borrowings. Journal of Financial Economics 70:3-28.

Fan, H. 1997. Design and Valuation of Debt Contracts. Ph.D. Dissertation, Columbia University.

Fan, H., and S. M. Sundaresan. 2000. Debt Valuation, Renegotiation, and Optimal Dividend Policy. Review of Financial Studies 13:1057-99.

Fischer, E. O., R. Heinkel, and J. Zechner. 1989. Dynamic Capital Structure Choice: Theory and Evidence. Journal of Finance 44:19-40.

Francois, P., and E. Morellec. 2004. Capital Structure and Asset Prices: Some Effects of Bankruptcy Procedures. Journal of Business 77:387-411.

Frank, M. Z., and V. K. Goyal. 2005. Tradeoff and Pecking Order Theories of Debt, in E. Eckbo (ed.), Handbook of Empirical Corporate Finance. New York: Elsevier.

Franks, J., and W. N. Torous. 1989. An Empirical Investigation of U.S. Firms in Reorganization. Journal of Finance 44:747-69.

Franks, J., and W. N. Torous. 1994. A Comparison of Financial Recontracting in Distressed Exchanges and Chapter 11 Reorganizations. Journal of Financial Economics 35:349-70.

Gertner, R. H., and D. S. Scharfstein. 1991. A Theory of Workouts and the Effect of Reorganization Law. Journal of Finance 46:1189-222. 
Gilson, S. C., K. John, and L. Lang. 1990. Troubled Debt Restructurings. Journal of Financial Economics $27: 315-53$.

Goldstein, R. S., N. Ju, and H. E. Leland. 2001. An EBIT-based Model of Dynamic Capital Structure. Journal of Business 74:483-512.

Graham, J. R. 2000. How Big Are the Tax Benefits of Debt. Journal of Finance 55:1901-41.

Harris, M., and A. Raviv. 1991. The Theory of Capital Structure. Journal of Finance 46:297-355.

Hart, O. 1995. Firms, Contracts, and Financial Structure. New York: Oxford University Press.

Hart, O., and J. H. Moore. 1994. A Theory of Debt Based on the Inalienability of Human Capital. Quarterly Journal of Economics 109:841-79.

Hart, O., and J. H. Moore. 1995. Debt and Seniority: An Analysis of the Role of Hard Claims in Constraining Management. American Economic Review 85:567-85.

Hege, U., and P. Mella-Barral. 2000. Bargaining Power and Optimal Leverage. Finance 21:85-101.

Hege, U., and P. Mella-Barral. 2005. Repeated Dilution of Diffusely Held Debt. Journal of Business 78:737-86.

Hennessy, C. A., and T. Whited. 2005. Debt Dynamics. Journal of Finance 60:1129-65.

Houston, J., and C. James. 1996. Bank Information Monopolies and the Mix of Private and Public Debt Claims. Journal of Finance 51:1863-89.

Johnson, S. 1997. An Empirical Analysis of the Determinants of Corporate Debt Ownership Structure. Journal of Financial and Quantitative Analysis 32:47-69.

Kane, A., A. J. Marcus, and R. L. McDonald. 1984. How Big is the Tax Advantage to Debt? Journal of Finance 39:841-53.

Krishnaswami, S., P. Spindt, and V. Subramaniam. 1999. Information Asymmetry, Monitoring, and the Placement Structure of Corporate Debt. Journal of Financial Economics 51:407-34.

Leary, M. T., and M. R. Roberts. 2005. Do Firms Rebalance Their Capital Structures? Journal of Finance 60:2575-619.

Leland, H. E. 1994. Corporate Debt Value, Bond Covenants and Optimal Capital Structure. Journal of Finance 49:1213-52.

Lemmon, M. L., and J. F. Zender. 2004. Debt Capacity and Tests of Capital Structure Theories, Working Paper, University of Utah.

Mann, R. 1997. The Role of Secured Credit in Small Business Lending. Georgetown Law Journal 86:1-44.

Mella-Barral, P. 1999. The Dynamics of Default and Debt Reorganization. Review of Financial Studies 12:535-78.

Mella-Barral, P., and W. Perraudin. 1997. Strategic Debt Service. Journal of Finance 52:531-56.

Miller, M. 1977. Debt and Taxes. Journal of Finance 32:261-75.

Moody's Investors Service. 2000. Bank Loan Losses given Default, special comment, Global Credit Research.

Nash, J. 1953. Two-Person Cooperative Games. Econometrica 21:128-40.

Osborne, M. J., and A. Rubinstein. 1990. Bargaining and Markets. San Diego, CA: Academic Press.

Rajan, R. G. 1992. Insiders and outsiders: The Choice Between Informed and Arm's Length Debt. Journal of Finance 47:1367-400.

Rajan, R. G., and L. Zingales. 1995. What Do We Know About Capital Structure? Some Evidence from International Data. Journal of Finance 50:1421-60. 
Repullo, R., and J. Suarez. 1998. Monitoring, Liquidation, and Security Design. Review of Financial Studies 11:163-87.

Rubinstein, A. 1982. Perfect Equilibrium in a Bargaining Model. Econometrica 50:97-109.

Schwartz, A. 1997. Priority Contracts and Priority in Bankruptcy. Cornell Law Review 82:1396-419.

Smith, C. W. Jr., and J. B. Warner. 1979. Bankruptcy, Secured Debt, and Optimal Capital Structure: Comment. Journal of Finance 34:247-51.

Strebulaev, I. 2004. Do Tests of Capital Structure Theory Mean What They Say? Journal of Finance forthcoming.

Titman, S., and S. Tsyplakov. 2003. A Dynamic Model of Optimal Capital Structure, Working Paper, University of Texas, Austin.

Weiss, L. A. 1990. Bankruptcy Resolution: Direct Costs and Violation of Priority of Claims. Journal of Financial Economics 13:137-51.

Welch, I. 1997. Why is Bank Debt Senior? A Theory of Asymmetry and Claim Priority based on Influence Costs. Review of Financial Studies 10:1203-36.

White, M. J. 1996. The Costs of Corporate Bankruptcy: A U.S.-European Comparison, in J. S. Bhandari, and L. A. Weiss (eds), Corporate Bankruptcy: Economic and Legal Perspectives. New York: Cambrige University Press. 